\title{
ABD Liderliğindeki Liberal Uluslararası Düzenin Sonu Tartışması: Liberalizmin Krizi ve Geleceği
}

\author{
The Debate Over the End of the US-Led Liberal International Order: \\ The Crisis of Liberalism and Its Future
}

\author{
Ömer KURTBAĞ $\breve{G}^{*}$
}

\section{Öz}

Bu çalışma, ABD öncülüğünde İkinci Dünya Savaşı sonrası kurulan liberal uluslararası düzenin varoluşsal bir kriz içinde olup olmadığını, Donald Trump’n Amerikan başkanlık seçimlerini kazanmasının ışığında ve Trump’ın selefi başkanların liberal düzene zarar veren geçmiş uygulamalarını dikkate alarak çözümlemeyi amaçlamaktadır. Savaş sonrası ABD liderliğinde kurulan ve Amerikan hegemonyasının (pax-Americana) oluşumundan ayrı düşünülmesi zor olan bu düzenin son yıllarda ağır bir krize girdiği ve yerini post-liberal bir düzene bırakıp bırakmayacağı ile ABD’nin hegemonyasındaki gerilemenin burada oynayacağı rol, son yıllarda özellikle Batılı ülkelerin akademik çevrelerinde ve medyasında yoğun bir şekilde tartışılmaktadır. Çalışmanın başlıca savı, liberal uluslararası düzenin, bugün esas olarak Çin gibi otoriter güçlerin yükselişinden değil, daha ziyade Batı dünyasında liberalizme ve küreselleşmeye düşman halk hareketlerinden de kaynaklanan ciddi bir tehdit altında olduğudur. Liberal uluslararası düzenin krizi gibi sistemik (küresel) bir olguyu çözümlemekle çalışma, John Ikenberry gibi otoriter devletler merkezli çözümleme yapan liberallerin başlıca çalışmalarının eleştirel bir okumasını sunma hedefindedir. Bununla da çalışma, öncelikle liberalizmin Batı içi liberalizm karşıtı popülist tepki kaynaklı bu krizi öngörmede başarısız olduğunu, ardından da liberallerin mevcut düzendeki krizin liberalizmin kendisinin değil ABD hegemonyasının krizi olduğundan hareketle eninde sonunda liberal düzenin bu çalkantıdan sağ çıkacağına dair yanlış bir inanca sahip olduğunu ileri sürmektedir. Çalışma, mevcut liberal düzenin yerini daha az liberal ve daha az Amerikan karakterli bir düzene birakacağ 1 tespitiyle sonuçlandırılacaktır.

Anahtar Kelimeler: Liberalizm, Liberal Uluslararasıcıllk, Liberal Uluslararası Düzen, Trump, ABD Hegemonyası

\section{Abstract}

This paper seeks to analyze the question of whether or not the US-led liberal international order entered into an existential crisis in the wake of the election of Donald Trump as the US President in 2016 as well as the harmful acts of his predecessors to the liberal order. There has been an ongoing and fierce debate over the end of US-led liberal international order and its future within the Western academia and media in recent times. The main argument of the study is that the post-1945 liberal international order

* $\quad$ Erciyes Üniversitesi, İktisadi ve İdari Bilimler Fakültesi, Uluslararası İlişkiler Bölümü, E-posta: omer.kurtbag@erciyes.edu.tr 
is now under serious threat, not only by the challenging rise of authoritarian powers such as China, but also due to the wave of illiberal popular movements within the Western World. Thus, by analyzing a systemic (global) phenomenon such as the crisis of the liberal international order, it presents a critical reading of the main works of liberals such as John Ikenberry whose analysis remains state based. By doing so, the contention is that liberalism has failed to predict this illiberal popular movementsoriented outcome, and falsely believes that the existing order is only the victim of its own success and will eventually survive the current disarray, since it is essentially a crisis of US hegemony rather than that of liberalism itself. The study concludes that this liberal order will gradually disappear and evolve eventually into a polity with less liberal and less American characteristics.

Keywords: Liberalism, Liberal Internationalism, Liberal International Order, Trump, US Hegemony.

\section{Giriş}

Bu çalışma, İkinci Dünya Savaşı sonrası kurulan liberal uluslararası düzenin yaşadığı güncel krizi ve bu düzenin sona erip ermediğini, ABD’de söz konusu düzene karşı çıan Trump yönetiminin işbaşına gelmesinden sonra başlayan tartışmalar çerçevesinde ele almayı amaçlamaktadır. Savaş sonrası ABD liderliğinde kurulan ve Amerikan hegemonyasının (pax-Americana) oluşumundan ayrı düşünülmesi zor olan bu düzenin son yıllarda ağır bir krize girdiği ve yerini post-liberal bir düzene bırakıp bırakmayacağı ile ABD’nin hegemonyasındaki gerilemenin burada oynayacağı rol, son yıllarda özellikle Batılı ülkelerin akademik çevrelerinde ve medyasında yoğun bir şekilde tartışılmaktadır. Türkiye’de ise, uluslararası ilişkiler camiası tarafından bu konunun yeterince ele alınmadığı ve çalışıldığında da daha çok Türkiye’nin dünya düzeni içindeki rolü ve konumu çerçevesinde irdelendiği gözlenmektedir. Çalışmanın bu noktada literatüre katkısı, John Ikenberry gibi liberal yazarların ABD ile rakipleri Rusya ve Çin'i baz alan devlet merkezli çözümlemelerinin ötesine geçip, liberalizme Batı́nın kendi içinden liberalizm aleyhtarı (illiberal) halk kitlelerinin ve bunların siyasi tercihlerinin yönelttiği tehdit kapsamında konuya yaklaşması ile krizin ABD hegemonyasından öte bizzat liberalizmin krizi olduğu tespitinde bulunması olacaktır. Bu tartışmalar ışı̆̆ında, söz konusu liberal düzenin ne amaçla ve nasıl kurulduğu, ABD hegemonyası ile bağlantısı ve bugüne kadar başarılı olup olmadığı çalışmanın ilk alt başlı̆̆ında değerlendirilecektir. İkinci alt başlıkta, liberal uluslararası düzenin hangi faktörlerin etkisiyle günümüzde krize girdiği üzerinde ayrıntılı biçimde durulacaktır. Üçüncü olarak çalışma, krize giren bu düzenin hangi yöne evrileceğini ve gelecekte devam edip edemeyeceğini, düzen kurma potansiyeli olduğu varsayılan $A B, A B D$ ve Çin'in bu noktadaki konumları ve duruşları ile $A B D$ başta olmak üzere Batılı ülkelerde liberal düzenin ciddi bir reformdan geçirilerek 1slah edilme olasılığı çerçevesinde tartışacaktır.

\section{2. İkinci Dünya Savaşı Sonrası ABD Liderliğindeki Liberal Uluslararası Düzenin Kuruluşu ve Gelişimi}

Liberal ilke ve değerlere dayalı bir dünya düzeni arayışı ve çabası 20. yüzyılın ilk çeyreğine, Wilsoncu idealizmin uluslararası ilişkilere hâkim olduğu döneme kadar götürülebilir. ABD Başkanı Woodrow Wilson'ın serbest ticaret, demokratik yönetimler, kendi kaderini tayin ve 
ilerlemeci değişim ihtimaline dayalı liberal vizyonuna, küresel bir kolektif güvenlik aygitı olarak da Milletler Cemiyeti’nin kurulması eşlik etmişti. Ancak Ikenberry tarafından "liberal uluslararasıcllı̆ıı ilk sürümü” (liberal internationalism 1.0) olarak tanımlanan bu düzen kurma girişimi, tüm iddiasına rağmen ekonomik bunalım, militarizm ve faşizmin yükselişi sonrası İkinci Dünya Savaşı’nın çıkışını önleyemeyerek başarısızlığa uğramaktan kurtulamadı (Ikenberry, 2009, s. 71-72). İkinci Dünya Savaşı sonrası kurulan liberal dünya düzeni ya da yine Ikenberry’nin (2009, s. 76) nitelemesiyle "liberal uluslararasıcılığın ikinci sürümü" (liberal internationalism 2.0) ise, aynı zamanda Amerikan hegemonyasının (pax-Americana) kuruluşundan ayrı bir gelişme değildi (Alcaro, 2018, s. 5). İki savaş arası dönemde yeniden yalnızcılığa dönerek ve Milletler Cemiyeti’ne katılmayıp dünya liderliği şansını kullanmayarak birinci sürümün başarısızlığında pay sahibi olan ABD, bu kez aynı hataya düşmedi. Daha savaş sırasında Başkan Franklin D. Roosevelt'in çabalarılya düzen kurma misyonunu üstlenen ve savaştan galip çıkan ABD, kapitalist Batı blokunun hegemonik lideri olarak, ekonomik bağlamda açık piyasalar ve çoktaraflı ekonomik kuruluşlara, siyasi/hukuki bağlamdaysa özgürlük, demokrasi ve hukukun üstünlügü̈ gibi değerlere dayalı liberal bir düzenin kurulmasına öncülük etti (Ikenberry, 2017, s. 2; Jahn, 2018, s. 45). ABD bu düzeni, kurduğu NATO ve SEATO gibi bir güvenlik ve ittifaklar ağı ile de tahkim etti ki, bu haliyle söz konusu düzen bir "güvenlik topluluğu" halini aldı. Bu liberal uluslararası düzenin kurumsallaşması ise, BM, NATO, IMF, Dünya Bankası, G-7 ve GATT gibi resmi ve gayri resmi nitelikli küresel düzenlemeler ve çoktaraflı kuruluşlarda somutlaştı. (Glaser, 2019, s. 56; Nye, 2017, s. 10-11; Ikenberry, 2010, s. 512; 2018, s. 15). Örneğin BM’nin kuruluş sürecinin miladı sayılan 1941 Atlantik Bildirisi’nin liberal uluslararası düzenin normatif temelini attığını söylemek yanlış olmaz. Avrupảnın zayıfllğ̆ ve artan Sovyet tehdidinin varlığı karşısında küresel kamu mallarının (global commons) sağlayıcısı olarak Amerikan gücü ve hegemonyası, kurulan bu açı ve kurala dayalı düzenin ekonomik, siyasal ve askeri anlamda sahibi, koruyucusu ve kollayıcısı olarak Soğuk Savaş yllları boyunca hayati bir rol oynadı (Alcaro, 2018, s. 5; Ikenberry, 2009, s. 76, 2011, s. 2; Duncombe \& Dunne, 2018, s. 32). Kagan’’n (2017) da altını çizdiği gibi, büyük güçler arası bir çatışmanın çıkmamış olması ve bunlar arasındaki rekabetin denetim altına alınması, 70 yıllık ABD liderliğindeki bu düzenin en mühim başarısıydı.

ABD öncülüğünde inşa edilen bu liberal kapitalist küresel düzen içinde Avrupalı devletler, savaşla sonuçlanan korumacılık gibi ekonomik ve ırkçılık ile faşizm gibi sosyal/siyasal tehlikeleri aşarak refah, istikrar ve barışı beraberinde getirme iddiasında olan bir sisteme eklemlendi (Mazarr, 2017, s. 25; Niblett, 2017, s. 18-19). Ekonomik anlamda bakıldığında, sistem gerçekten de savaş sonrası kapitalizmin "altın çağı" denen bir sürekli büyüme dönemini mümkün kıllmıştı (Ikenberry, 2010, s. 513). 1944 Bretton Woods düzenlemeleri sonrasında Amerikan doları uluslararası rezerv para rolü oynarken, Amerikan ulusal pazarı da "küresel ekonomik büyümenin motoru" (Ikenberry, 2009, s. 77) vazifesi gördü. Dahası, Özel’in de işaret ettiği üzere, "İkinci Dünya Savaşı sonrasında gelişmiş demokratik ülkeler kurgulamış oldukları refah sistemleri sayesinde meşruiyetlerini sağlama bağladılar. Bu tür bölüşümcü sistemlerin varlığı, çalışan kesimlerin dünya tarihinde ilk kez yaratılan değerden hatırı sayılır bir pay almaları demokratik rejimlerin sürdürülebilirliğini kolaylaştırdı" (Özel, 2016). Ruggie’nin (1982, s. 380) "gömülü liberalizm” (embedded liberalism) 
dediği bu sistemde, çalışan sınıfların uğrayabilecekleri kayıpları dikkate alan refah sistemleri ve emek politikaları, piyasa güçlerinin önceki dönemdeki gibi toplumdan kopmasını ve ekonomiyi krize sürüklemesini önleyen bir işlev görüyordu. Öte yandan, bazılarına göre bu tür bir ekonomik modelin gerçekten "liberal" olup olmadığı tartı̧malıydı. Zira sermaye sınırları aşıp serbestçe dolaşmamakta ve kontrol altında tutulmaktaydı. Bretton Woods'un sabit kur sistemi altında döviz kurlarının piyasaca belirlenmesi söz konusu olmadığı gibi, GATT ile düzene sokulmaya çalışlan serbest ticaret sistemi de zar zor ve ağır aksak işlemekteydi (Tooze, 2019).

ABD merkezli bu liberal uluslararası düzen, Soğuk Savaş boyunca devletler arasında çok taraflı işbirliğini teşvik etmenin ötesinde, sistemdeki büyük güçler arası bir sıcak savaşın önüne geçmeyi de başardı (Colgan ve Keohane, 2017, s. 37). Elbette ABD bu düzenin sahibi ve koruyucusu olarak birtakım özel avantaj ve ayrıcalıklara sahipti (Ikenberry, 2009, s. 72; Mazarr, 2017, s. 26). Başka bir deyişle, söz konusu düzen, liberal karakterde ama aynı zamanda da hiyerarşik bir oluşumdu. Bununla birlikte, Patrick’in de ifade ettiği gibi, “1945’ten beri Birleşik Devletler dünya düzeninin ve bölgesel güç dengelerinin nihai garantörü olarak hareket etmişti. İleri üslerdeki askeri varlığı, sağladığı nükleer şemsiye ve savunma güvenceleri, başka türlü koşullarda anarşik bir küresel sistem içinde kendi başlarının çaresine bakmak zorunda kalacak birçok ülke için güvenliği sağlamıştı." (Patrick, 2017, s. 53) ABD, hegemon güç olarak kurulmasina ön ayak olduğu bu düzen yoluyla tüm dünyada barış, refah ve istikrarın sağlanmasını kendi dar ulusal çıarlarının bile önüne koyan iyicil (benevolent) bir küresel hegemon olarak hareket etmişti. Nitekim başta Almanya ve Japonya olmak üzere kimi ülkeler, bu sistem içinde ABD’nin ikili ya da NATO gibi çok taraflı ittifak sistemleri sayesinde sağladığg güvenlik şemsiyesinden de yararlanarak ekonomik kalkınmalarını sağlamayı başarmışlardı (Niblett, 2017, s. 18-19). NATO ve Avrupa bütünleşmesi de, Avrupa tarihinin en önde gelen jeopolitik meseleleri olan Fransız-Alman rekabetini ve Almanyảnın kıtadaki konumunun ne olacağı sorununu çözüme bağlamıştı. Hatta Soğuk Savaş่ı barışçıl biçimde sona ermesi ve Doğu Avrupa ile eski Sovyet bloğu ülkelerinin uluslararası sisteme çatışmasız biçimde eklemlenmesi de bu liberal düzenin başarısıydı. Gerçekten de, bu düzen katılması kolay, zahmetsiz bir düzendi ve Çin'in DTÖ’ye katılımı ya da G-7/8'in yerini G-20'nin almasında da gözlenebileceği gibi, yeni paydaşlara da kapıyı açı tutmaktaydı. $\mathrm{Bu}$ paydaşlar sorumlu davrandıkları sürece, yani sisteme meydan okuma, onu yıkma ve yerine yenisini kurma gibi eylemlere girişmedikleri ya da bu yönde bir blok ya da koalisyon etrafında toplanmadıkları sürece, sistemin de açık ve kapsayıcı doğasında değişikliğe gerek yoktu. Bir yandan küreselleşmeyle beraber gelen ekonomik karşılıklı bağımlılık sayesinde enerji ve çevre koruması başta olmak üzere ekonomik, diğer yandan ise terörizm ve başarısız devletlere yönelik siyasi kaygılar, sistemin yeni paydaşları ile Batılı sahipleri arasında ortak çıar alanları oluşturdu ve bu da sistem karşııı meydan okumaların önüne geçti. Kısacası, yükselen güçlerin ve sisteme dâhil olan yeni ulusların liberal olmayan bir dünya düzeninden herhangi bir çıkarları olmadığı düşüncesi hâkimdi (Ikenberry, 2010, s. 513-515).

Ancak liberal uluslararası düzene ve dolayısıyla pax-Americanảya ilişkin olumlayıcı bu liberal okumaya muhalif görüşler de vardır. Nitekim Neorealist ekolden Mearsheimer (2018), Soğuk Savaş dönemindeki dünya düzeninin ne liberal ne de hakikaten uluslararası olduğu kanaatindeydi. 
Liberal değildi, zira liberalizm değil realizmin mantık, ilke ve değerleri üzerine kurulmuş bir düzendi. Hakiki anlamda evrensel bir düzen de değildi, zira sadece Atlantik dünyası ile sinırlı ve Batı merkezli bir karaktere sahipti. Bu yönleriyle de söz konusu düzen daha baştan başarısız olmaya mahkûmdu ve kendi başarısızlığının tohumlarını bünyesinde taşımaktaydı. Özellikle de liberal demokrasinin tüm dünyaya yayılması hedefinin buna muhatap olan uluslarca milliyetçi tepkilerle karşılanması kaçınılmazdı. Glaser (2019, s. 64) da, benzer şekilde liberal uluslararası düzenin esasen Soğuk Savaş dönemindeki göreli istikrar ve barışın sağlanmasında mühim bir payı olmadığını savunarak, bunun sebeplerini hem bu düzenin kısmi nitelikte olmasına hem de içe dönük olmasına bağlamaktaydı. Başka bir deyişle, söz konusu düzen tüm büyük güçleri kapsamadığı için kısmi, sadece düzene dâhil devletler arası ilişkileri düzenleyip düzenin dışında kalanlar ile ilişkilerin nasıl yürütüleceğini düzenlemediği için de içe dönüktü. Parmar (2018, s. 157) ise, bu liberal düzenin Avro-Atlantik ulusların dünya düzenini yönetmesini sağlayan ve Batı dışında kalanlara karşı farklı kurallara dayanan dışlayııı, dayatmacı ve neo-emperyal bir karaktere sahip olduğu tespitiyle, Ikenberry’ye liberal uluslararasıcılığın bu yönünü görmezden gelme eleştirisi getirmekteydi.

Özetle, ekonomik refah, askeri güvenlik ve büyük güçler arası barışçıl ilişkilerin korunması anlamında liberal uluslararası düzenin, en azından kendinden önceki Wilsoncu benzerine kıyasla çok daha başarılı olduğu açıktı, hatta muhtemelen "şimdiye kadar dünyanın gördüğü en başarılı uluslararası düzendi” (Ikenberry, 2010, s. 513). Bu iddialı tespite rağmen Tooze, söz konusu düzenin aradan geçen zamanda İkinci Dünya Savaşı sonrası kurulan düzenden hayli farklılaştığına ve bu farklılığın da 1970'lerde Bretton Woods sisteminin çökmesinin bir sonucu olduğuna dikkat çeker. Nitekim liberal düzenin ekonomik ayağında gerçekleşen ve gömülü liberalizmden neoliberalizme geçişle tamamlanan bu dönüşüm, 1970'lerdeki kaosun bir sonucuydu ve bu hiç de savaş sonrasının bilgece düzenlenmiş kolektif aklının ürünü bir liberal düzen gibi durmuyordu. Dolayısıyla günümüzde krize giren de, aslında bu şekil ve içerik değiştirmiş ve savaş sonrasındaki görünümünden hayli farklılaşmış olan (neo)liberal uluslararası düzendi. Bu krize yol açan iki önemli dönüm noktasından ilki Soğuk Savaş̧ın bitişi, ikincisi ise 11 Eylül saldırılarıydı.

Aslında Soğuk Savaş bittiğinde liberal düzenin, açık ve kapsayıcı doğasından dolayı yükselişe geçen ülkeleri de içine alarak genişletilebileceği yönünde iyimser beklentiler yok değildi (Ikenberry, 2010, s. 513). Nitekim Soğuk Savaş yıllarında liberal uluslararası düzen sadece Atlantik dünyası ile sınırlı ve bölgesel ölçekli kalmış, evrensellik özelliği gösterememiş bir alt sistemdi (Ikenberry, 2018, s. 11-12, 18). Soğuk Savaş sonrasında ise artık tehdit SSCB gibi devlet kaynaklı olmaktan ziyade çok daha çeşitli kaynaklardan gelmekteydi ve bunlar arasında küresel ısınma, küresel salgınlar, nükleer silahların yayılması ve radikal dinci terörizm öne çıkmaktaydı. Bu tehditler karşısında devletler güvenlik anlamında da daha karmaşık bir dünya ile karşı karşıyaydı ve bu da, devletler arasında güvenlik alanında sıkı işbirliğini gerekli hâle getirmekteydi (Ikenberry, 2010, s. 518519). Ikenberry (2018, s. 7), Doğu Asya, Doğu Avrupa ve Latin Amerikảnın demokratikleşerek dünya ekonomisiyle bütünleştiği; kurumsal boyutta da NATO’nun genişlediğii, DTÖ’nün kurulduğu ve G-20’nin ortaya çıktığ 1 tespitiyle, liberal düzenin Soğuk Savaş sonrasında tüm dünyaya yayıldığını ve böylece gerçek anlamda küresel bir düzen halini aldığını savunmaktaydı. 
Ayrıca ABD'nin SSCB'nin yıkılmasıyla rakipsiz kalması ve tekkutuplu bir hegemonyanın ortaya çıkışı da, ABD’nin bu üstünlüğünü kendi dar ulusal çıkarlarına öncelik vermek yerine herkesin iyiliğine kullanacağı beklentisiyle, liberal düzenin küreselleşmesi açısından fırsatlar sunmaktaydı (Ikenberry vd., 2009). Bu tabloya bakınca, tüm dünya liberal uluslararasıcı bir istikamette ilerliyor gibi görünüyordu. Ikenberry’nin kendi ifadesiyle, "Savaş sonrası liberal düzenin gerçekte küresel bir düzen olmadığını hatırlamak önemlidir. Bu düzen iki kutuplu Soğuk Savaş sisteminin bir kutbu içinde inşa edilmişti. Küresel bir Soğuk Savaş açma büyük jeopolitik projesinin bir parçasıydı. Batı, Amerikan liderliği ve Sovyet komünizmine karşı küresel mücadele ile bağlantılı pazarlıklar, kurumlar ve sosyal amaçlar etrafında inşa edilmişti. Soğuk Savaş sona erdiğinde, bu dâhili düzen harici düzen haline geldi. Sovyetler Birliği çöktügü için liberal uluslararasıcıllğın büyük rakibi de ortadan kalkmıştı ve Amerikan-liderliğindeki liberal düzen dışa doğru yayıldı. Soğuk Savaş่ın sonu ile, liberal uluslararasıcılık küreselleşti” (Ikenberry, 2018, s. 9-10). Hatta Jahn’a (2018, s. 47) göre, uluslararası alanın bu şekilde daha da liberalleşmesi ve liberal uluslararasıcılığın tüm dünyada rakipsiz kalması sayesinde Batı’nın artık kendi evine çeki düzen vermesi ve Batılı demokrasilerin kendi içlerinde 1930'lardaki gibi ilerici reformları yapmaları mümkün hâle gelmişti. Ancak küreselleşen bu savaş sonrası liberal düzenin üzerine kurulduğu eski pazarlıklar, uzlaşılar ve düzenlemeler 21. yüzylla girilirken giderek yetersiz gelmeye başladı.

Öte yandan, 11 Eylül terör saldırıları bu liberal iyimserliğe büyük bir darbe indirdi. Rusya, Çin ve Brezilya gibi yükselen güçler, özelikle 11 Eylül olayı sonrasında ABD’nin, mimarı olduğu düzenin kural ve normlarıyla gerekirse ters düşmekten çekinmeyeceğini ve artık kendi dar ulusal çıarlarını düzenin iyi huylu ya da diğerkâm sahibi ve koruyucusu olmanın önüne koyabileceğini gördüler. Jervis (2009, s. 204) de, Soğuk Savaş bittiğinde ABD’nin geride kalan tek süper güç olarak muhafazakâr bir eğilime sahip olacağı ve kendi lehine olan statükoyu korumaya çalışacağ görüşünün doğru çımadığını ve özellikle 11 Eylül saldırılarından sonra Washington’n tam aksi yönde davrandığını savunmaktaydı. Jahn’n (2018, s. 43) tespitiyle, "2000’lerin başında Bush yönetimi altında Birleşik Devletler liberal uluslararasıcıllğı tümüyle terk etmiş görünmekteydi. Çok taraflllığı tek taraflılığa değişmiş, dostları ve müttefiklerine uzak durmuş, uluslararası kuruluşları görmezden gelmiş, saldırgan ve hukuk dışı bir dış politika izlemiş ve insan haklarını da fena halde ihlal etmişti." Böyle davranan bir Washington’ın, kendisinin ilke ve kurallarını sahiplenmediği veya bunlara saygı göstermediği bir liberal düzene başkalarının uymasını beklemesi veya onları buna zorlaması da artık inandırıcı değildi. Bu da, düzenin temel dayanaklarının ve meşruiyetinin diğer ülkelerce sorgulanmasına yol açtı ve aynı ülkelerden giderek sistemin daha kapsayıcı, çoğulcu ve demokratik hale getirilmesi yönünde çağrılar yükselmeye başladı (Mazarr, 2017, s. 26-27).

Nitekim Ikenberry, liberal uluslararasıcılığın sonu tartışmasının yoğunlaştığı 2016-2017'den çok önce, 2011 tarihli Liberal Leviathan başlıklı kitabında (s. 6) liberal uluslararasıcılığın ikinci sürümünün, kendi başarısının sonucu bile olsa, krizde olduğunu ilan etmişti. Bu kriz durumunu da, Amerikan hegemonyasının artık liberal bir uluslararası düzeni ayakta tutmaya yetmediği ve liberal projenin temel ilke ve kurumlarının giderek sorgulandığı tespiti ile ortaya koymaktaydı. Peki, liberal düzendeki bu krize hangi değişimler ve dönüşümler yol açmıştı? 
Bu noktada öncelikli olarak, artık ABD’nin güvenlik garantörlüğüne soyunduğu ve bundan kaynaklanan sorumluluklar üstlendiği iki kutuplu bir dünya yoktu. Böyle bir dünyada ABD sistemin istikrarı için kendini dizginlerken sağladığı kamu malları sayesinde müttefiklerinin de sadakatini temin edebiliyordu. Oysa şimdi Soğuk Savaş bitince bu durum ciddi şekilde değişmişti ve hem ABD hem de hegemonyaya tabi ülkeler için işbirliğini mümkün kılan güdüler zayıflamıştı. İkinci olarak, ABD hegemonyasının Soğuk Savaş sonrasında tekkutuplu bir dünyada da sürmesinin Amerikan gücünü daha tartışmalı hale getirmesi ve bunun liberal uluslararası düzenin işleyişi açısından çıkardığı zorluk da dikkat çekiciydi. Nitekim Soğuk Savaş döneminde güvenlik amaçlı işbirliği ile sonuçlanan pazarlık süreçleri ve liberal kurumsallaşma artık diğer kutbu dengeleme ihtiyacı ortadan kalktığı için işlememeye başlamıştı ve bu da hegemonyaya tabi uluslar için alışılmadık ve rahatsız edici bir durumdu. Üçüncü olarak ise, Soğuk Savaş sonrası insan haklarının artan önemi ve insan hakları ihlallerinin dışarıdan askeri müdahaleye konu olabileceğine dair "koruma sorumluluğu” olarak anılan doktrinin öne çıması bir başka sorundu (Niblett, 2017, s. 18). Bu yeni ama aynı zamanda Westfalyan egemenlikle bağdaşmayan müdahaleci anlayışın yarattığı şüphe ve kaygılar da, Haass'ın (2017, s. 2) vurguladığı üzere, sistemin istikrarı açısından tehlikeliydi. Bu şüphe ve korkuların gerisinde, uluslararası ilişkilerin Westfalyadan beri en yerleşik kurumlarından birinin insan hakları gerekçesiyle aşındırılması ve bu gerekçenin de büyük güçler tarafından zayıf devletlere karşı müdahale amacıyla bir koz olarak kullanılması yatmaktaydı. Nitekim Jahn'ın (2018, s. 46) tespitiyle, bu tür müdahaleler hayli seçmeci biçimde uygulanmış ve çoğu zaman da müdahaleye konu olan ülkeleri kaosa, istikrarsızlığa ve hatta iç savaşa sürükleyerek sonuçlandırılmıştı. Son olarak da Ikenberry, uluslararası ilişkilerin Soğuk Savaş sonrası dünyasında güvenlik tehditlerinin büyük güçlerden ve bunlar arasındaki rekabetten ziyade devlet dişı aktörlerden geldiğine dikkati çekmekteydi. Bu noktada, Soğuk Savaş döneminde büyük güçler arasındaki en uzun barış dönemiyle de sonuçlanan bu ortamı mümkün kılan ise, nükleer caydırıcılık ile demokrasinin hâkim yönetim şekli olmasıydı (Ikenberry, 2010, s. 514). $\mathrm{Bu}$ iki sütun, iki savaş arası dönemdeki gibi uluslararası düzeni bozma ve yıkmaya yeltenebilecek güçlerin ve dinamiklerin ortaya çıkmasını önlemeyi başarmıştı. 2000’lere gelindiğinde ise, bu iki sütunun ikisi de artık bir hayli kuşkulu hale gelmişti. Nitekim nükleer caydırıcılık sistemi yeni nükleer güçlerin ortaya çıkışını önleyemediği gibi, ABD George W. Bush döneminde Anti-Balistik Füzeler (ABM) anlaşmasından çekilip tek taraflı adımlar atmaktan çekinmemişti. İkinci sütuna gelince, özellikle 2008-09 Küresel Mali Krizi sonrasında gerek Avrupa’da gerekse de ABD’de sağ ve sol popülist veya aşırılıkçı akımların/partilerin yükselişiyle sonuçlanan bir demokratik gerileme dönemine girildiği söylenebilir. Aşağıda, bu arka plan üzerinden liberal düzenin güncel krizinin gerisindeki sebepler ve bunun yol açtığı ekonomik ve siyasi sonuçlar ele alınacaktır.

\section{Liberal Uluslararası Düzenin Güncel Krizi ve Bunun Sonuçları}

Liberal uluslararasıcılığın ikinci sürümünün krizde olduğunu kabul eden yukarıdaki liberal çözümleme, aynı zamanda bu eskiyen liberal dünya düzeninin reformdan geçirilmesi ve yeniden örgütlenmesi yönünde diğer devletlerden gelebilecek baskıların da artması beklentisi içindeydi. Burada Ikenberry (2009), liberal uluslararasıcılığın geleceğine dair üç farklı öngörüde 
bulunmaktaydı: birinci olasılık liberal uluslararasıcıllğın üçüncü sürümüne geçilmesi, ikinci olasılık liberal uluslararasıcılığın ikinci sürümünün kısmen dönüştürülmesi ve üçüncü olasılık da liberal uluslararası düzenin çöküşüydü. Dolayısıyla, üçüncü olasılık ile günümüzdeki durum örtüşmekle birlikte, bu çöküşün neden ve sonuçları yine devlet merkezli olarak çözümlenmekteydi. Başka bir deyişle, sistemin daha kapalı hale gelmesi ve kural temelli olmaktan çıkması halinde bu çöküşün mümkün hâle geleceğini öngören Ikenberry, bunun olası sonucunun da rakip jeopolitik blokların ortaya çıkması şeklinde tezahür edebileceğini düşünmekteydi. (Ikenberry, 2009, s. 81$83)$.

2018'deki makalesinde ise Ikenberry (s. 10), liberal düzenin krizinin yukarıda özetlenen şekliyle bir "E. H. Carr krizi” değil, aksine bir "Polanyi krizi” olduğunu saptayarak bu devlet merkezli çözümlemeden uzaklaşmıştı. Nitekim bununla kast ettiği ise, krizin iki savaş arası dönemde Carr’n Yirmi Yıl Krizi kitabında çözümlediği gibi büyük güç politikasının ve jeopolitik rekabetin geri dönüşünün yol açtığı bir kriz olmayıp, küresel kapitalizmin ve piyasacı anlayışın tüm dünyaya yayılmasının ve hâkim olmasının yol açtı̆̆ı istikrarsızlıklarla kendini gösteren bir Polanyi krizi olduğu idi. Karl Polanyi (2002), piyasa ekonomisinin siyasal müdahale olmaksızın hiçbir şekilde kendi dinamikleriyle işlemediğini ve zaman içinde toplumdan koparak birçok sosyal huzursuzluğa ve siyasal soruna yol açtığını daha 1940’larda tespit etmişti ve bu tespit bugün yeniden anlam kazanmıştı. Bu anlamda kriz, liberal düzenin kurulduğu ve geliştirildiği siyasi temelleri de kökünden sarsmaktaydı.

Dolayısıyla, günümüzde mevcut liberal düzenden duyulan memnuniyetsizlik artık sadece dışardan, yani Batı dışı devlet aktörlerden kaynaklı değildi. 2000'lerin başlarından beri sistemin meşruiyeti içerde de ciddi şekilde sorgulanmaya başlamıştı. Soğuk Savaş sona erdiğinde, Fukuyama gibi kimi analizciler, geçmişte Nazizm ve Komünizmi alt eden liberal demokrasilerin insanlığın ulaştığı en mükemmel yönetim şekli olduğuna dikkat çekerek "tarihin sonu"nu bile ilan etmişlerdi. Oysa Ikenberry'ye (2018, s. 18) göre, "krizin tohumları tam da bu zafer anında atılmıştı." Nitekim Fukuyama tarzı iyimserlik, aradan geçen yaklaşık 30 yıllık dönemde, tam tersi bir tabloya evrilmiş durumdadır ve bugün liberal demokrasinin ağır bir krize girdiği yönünde güçlü emareler bulunmaktadır. Kimileri artık bütünleşme değil parçalanma yaratan güçlerin işbaşında olduğuna dikkat çekerken (Walt, 2016), bir siyaset bilimcinin tabiriyle de, dünya bir "demokratik durgunluk" (democratic recession) dönemine girmiş olabilir (Niblett, 2017, s. 18). Bu da, "bireysel özgürlüklerin ve demokrasinin yayılma sürecinin, tersine dönmediyse bile, durmuş olduğu" (Niblett, 2017, s. 18) anlamına gelebilir. Öte yandan, kapitalizmle demokrasinin birbiriyle ne kadar uyumlu olduklarına yönelik olarak Dani Rodrik (2011) de, küreselleşmenin ülkeleri bir üçleme (trilemma) sürüklediğine dikkat çeker: demokrasi, küreselleşme ve ulusal egemenlikten ancak ikisinin bir arada olabileceği ve dolayısıyla bunlardan birinin mecburen feda edileceği. Şu anda da, liberal demokrasi küreselleşmenin yarattığı büyük tahribat ve sorunlar nedeniyle zora girmiş durumdadır.

İlginç olan husus, Ikenberry gibi liberallerin, küresel mali kriz sonrasındaki analizlerinde, liberal düzenin geleceğini etkileyebilecek ve şekillendirebilecek gelişmeler arasında, Çin’in 
başlıca kutuplardan birini oluşturabileceği çok kutuplu bir dünyanın ortaya çıkması ile Brezilya, Meksika, Türkiye ve Endonezya gibi orta boy devletlerdeki olası siyasi istikrarsılılklar ve krizleri sayarken (Ikenberry, 2010, s. 519-520) Batı’nın kendi içinde liberal sisteme açıç̧a meydan okuyan (illiberal) muhalif siyasi akım ve hareketleri öngörememiş olmasıdır. Ikenberry ancak 2015’teki makalesinde, küresel yönetişime en ciddi tehdidin liberalizmin Batılı olmayan ülkelere hizmet edememesinden değil, küreselleşmeden zararlı çıkan Batılı toplumlara hizmet edememesinden kaynaklandığı tespitinde bulunabilmiştir. Başka bir deyişle, savaş sonrası uluslararası yönetişime en beklenmedik muhalefet kendi kalbinden gelmektedir. Liberallerin, bunu öngöremedikleri gibi, günümüzde bu içerden gelen liberalizm ve küreselleşme karşıtı güçlü dip dalgayı liberal düzenin karşısındaki esas tehdit saymaları (Nye, 2017, s. 14; Niblett, 2017, s. 18; Colgan ve Keohane, 2017, s. 36) da dikkat çekicidir. Nitekim Ikenberry’nin Trump’n başkan seçilmesine atfen sarf ettiği sözler çarpıcıdır: "Gerçekten düşmanca bir revizyonist güç sahneye çıktı ama bu güç özgür dünyanın kalbinin attığı yerde, Oval Ofis’te ikamet ediyor. Kadim ve modern çağlar boyunca büyük güçlerin inşa ettiği düzenler geldi ve geçti - ama bunlar genellikle diğer güçlerin elinde son bulmuştu, intihar ederek değil!" (Ikenberry, 2017, s. 1). Oysa Mearsheimer (2019, s. 7), liberal düzenin krizinin liberallerin öne sürdüğü gibi Trump’a bağlanamayacağı ve bunun gerisinde çok daha köklü nedenler olduğu görüşündedir. Ona göre, bu düzen çöküşün tohumlarını zaten bünyesinde taşımaktaydı. Öncelikle, bu sözde liberal uluslararası düzende liberal demokrasinin yayılması yönündeki Amerikan çabaları Afganistan ve Irak’ta olduğu gibi başarısızlıkla sonuçlanmıştı. Bu tür rejim değişikliği amaçlı çabalar söz konusu ülkelerde milliyetçi direnişle karşılaşmış ve başarısız olmaktan kurtulamamıştı. İkinci olarak liberal düzen egemenlik ve ulusal kimlikle ilgili ortaya çıkan siyasal krizlerin de sorumlusuydu. Zira çevre ülkelerde başarısız rejim değişikliği girişimleri Batılı ülkelere doğru düzensiz göçe yol açmakta ve bu da Batı dünyasındaki milliyetçi tepkileri tetiklemekteydi. Üçüncüsü de, hiper küreselleşme olgusu liberal demokrasilerde giderek gelir eşitsizliği ve işsizlik gibi ağır ekonomik faturalar çıkarırken Çin gibi ülkelerin ise aynı olguyu lehlerine kullandığı görülmekteydi. Mearsheimer gibi Mazarr (2017) da, Batılı liberal demokrasilerdeki öfkeli milliyetçi dip dalganın üç nedeni olduğunu tespit eder: birincisi, neoliberal küreselleşmenin yarattığ 1 ekonomik eşitsizlikler ile bozuk gelir dağılımı, ikincisi, düzensiz göçün de katkıda bulunduğu demografik ve kültürel değişim ve üçüncüsü de, ulusal egemenlik kaybı.

İçerde ve dışarda nasıl işlediği yukarıda kısaca özetlenen bu liberal düzeni bozan en öncelikli faktör, ekonomik olduğu kadar ideolojik ve siyasi bir proje de olan neoliberal küreselleşmenin içine girdiği krizdir. Bretton Woods sisteminin yıkılıp ekonominin giderek finansallaşmasını ifade eden neoliberalizm ideolojisinin ve buna dayalı Washington Mutabakatının (The Washington Consensus) Batı dünyasında $1980^{\prime}$ lerden itibaren ekonomiye ve siyasete hâkim olduğu ${ }^{1 * *}$ görülmektedir. Özellikle piyasacı neoliberal modelin iflası anlamına gelen ve ağır sonuçlar yaratan 2008-09 Küresel Mali Krizi sonrasında Batılı neoliberal ekonomilerin içine girdiği kriz,

1 Küreselleşme literatüründe, bu olgunun 19. yüzyllın sonunda da en az bugünkü kadar hızlı ve yoğun olduğuna yönelik çalışmalar bulunmaktadır. Hatta Frankel küreselleşmenin literatürde bağımsız bir değişken olarak kullanılmasına da karşı çıkmakta ve günümüzdeki küreselleşme literatürüne bu anlamda eleştiriler getirmektedir. (Bkz. Frankel, 2000). 
aradan on yıl geçmeden küreselleşmeye karşı çok ciddi ve yıkıcı bir "geri tepki" (backlash) üretti (Cox, 2019, s. 260-261). Nitekim Özel'in kaydettiği gibi, bu liberal düzen, "son 30 ylla damgasını vuran piyasacı yaklaşımlar ve gelişmekte olan ülkelerin küresel piyasalara dâhil olarak, üretimi kendilerine çekmelerinin de katkısıyla sarsıldı" (Özel, 2016).

Meselenin "piyasacı yaklaşımlar" kısmında, özellikle de finans piyasalarının yarattığı refahtan Batılı orta ve alt sınıfların hiç istifade edemediği gerçeği dikkat çekiciydi. Özellikle ABD'de, 1980 'lerden beri yaratılan refahın neredeyse tamamı en zengin \%20'lik kesime ve bunların içinde de özellikle en zengin \%1'e gitmişti. (Ikenberry, 2018, s. 20-21). 2018 yılı Dünya Eşitsizlik Raporu’na göre, en üst \%10'luk gelir dilimindeki zenginlerin milli gelirden aldıkları pay Avrupa’da \%37, ABD'de \%47 ve Orta Doğu'da \%61'e ulaşmıştı. Yine ABD'de en alt \%50'lik kesimin milli gelir payı 1980'de \%20 iken 2016'da \%13’e kadar inmişti (Dünya Eşitsizlik Raporu, 2018, s. 9-10). Diğer yandan da, küresel mali kriz öncesinde, sorumsuzca riskli yatırımlar yapan finans sektörü ve bankalara yönelik iyice gevşetilmiş düzenlemeler ile kriz sonrası batan finansal kuruluşlar ve bankaların devlet tarafından trilyon dolara varan yüksek meblağlarla kurtarılmasının vergi verenlere getirdiği yük, sıradan vatandaşların devlete ve ekonomik seçkinlere olan güvenini iyice sarstı. Nitekim sermaye piyasalarının açıklığı da, orta ve alt sınıfların çıkarına değil, zaten varlıklı olan ekonomik seçkinlerin çıkarına işleyen bir neoliberal ilke halini çoktan almıştı (Niblett, 2017, s. 19).

Özel'in tespitinin ikinci kısmında ise, piyasacı anlayışın serbest ticaret rejimi ve ihracata dayalı büyüme modelinin sonucu olarak, sanayi üretiminin Batı'dan Çin başta olmak üzere gelişmekte olan dünyaya doğru kayması olgusu, Batılı toplumlardaki küreselleşme karşıtı dalganın diğer sebebiydi. Üretim Çin gibi ucuz emek vaat eden çevre ülkelere kayınca buradan gelen kalitesiz ama ucuz mallar Batılı ülkelerde enflasyonun artmasını önlemekle birlikte, aynı zamanda hem sanayideki milyonlarca işi yok etti hem de işçi ücretlerindeki büyük artışları önledi. Son yıllarda, bu sanayisizleşmeye (deindustrialisation) bir de otomasyon ve robotlaşmanın yarattığı yeni iş kayıpları eklenmeye başladı (Hu ve Spence, 2017, s. 58). Batı'da mavi yakalı işler yok olurken ve bu kesimin geliri ya azalır ya da sabit kalırken, Çin ve Hindistan gibi hızlı ve yüksek oranda büyüyen ülkelerde yeni orta sınıflar oluşmaya başlamıştı bile. Nitekim Colgan ve Keohane'in (2017, s. 38) de tespit ettiği gibi, 1974-2015 arasında üniversite mezunu olmayan Amerikalıların ortalama hane halkı gelirinin neredeyse \%20 düştüğü gözlenmekteydi. Dolayısıyla, Batı’nın öncülük ettiği ekonomik, finansal ve ticari küreselleşme sürecinden artık Batılı ekonomiler ve sinıflar değil, Asyadaki ve diğer bölgelerdeki gelişmekte olan ekonomiler ve onların yoksulluktan kurtulup orta sınıfa atlayan işçileri kârlı çıkmaktaydı. Sanayisizleşmeyle rekabetçiliği zarar gören Batı ise, yüksek maliyetli sosyal refah devleti politikalarını, artan yaşlı nüfus baskısının da etkisiyle, artık sürdürememe riskiyle yüzleşmek durumunda kaldı (Niblett, 2016). Gömülü liberalizmden geriye neredeyse hiçbir şey kalmamıştı ve piyasa ile toplumun bağlantısı tümüyle kopmuş; bu da Batılı toplumların liberalizme ve liberal uluslararasıcılığa olan inancını derinden sarsmıștı (Ikenberry, 2018, s. 21). Sosyal devlet geleneğine sahip olmayan $A B D$ ve Britanyadda ise durum daha da kötüydü. Zira yoksullarla zenginler arasında gelir ve refah düzeyinde artan eşitsizliği giderici politikalar gerek liberal siyasi seçkinlerin umursamazlı̆̆ gerekse de siyasetin işlevsizleşmesi 
yüzünden hayata geçirilemedi (Hu ve Spence, 2017, s. 59). Küreselleşme karşıtı tepkinin, ya da Ulagay'in (2017, s. 80) nitelemesiyle "geride kalanların" isyanının, Brexit ve Trump'n zaferi örneklerinde olduğu üzere en keskin biçimde bu iki ülkede görülmesi bu anlamda tesadüf değildi.

Küreselleşme ve beraberindeki olumsuzluklardan dolayı ekonomik ve siyasi seçkinlere öfkeli kitleler, çareyi, kendi geleceklerini kendileri belirlemekte ve kaybettiklerine inandıkları ulusal egemenliklerini yeniden tesis etmek için popülist bile olsa siyaset dışından gelen, düzene karşı duran ya da durduğu iddiasında olan siyasal figür ve akımları desteklemekte buldular (Hu ve Spence, 2017, s. 59). "Yerleşik düzeni" (establishment) temsil eden siyasi parti ve hareketlerin küreselleşmenin yarattığı sorunlara kitleleri ikna edici çözüm üretmekte yetersiz ve çaresiz kalması da, siyasetteki bu altüst oluş sürecinde etkili oldu. Krastev’e (2016) göre, Brexit öncesi ve sonrası Avrupa’da yükselişe geçen aşırı sağcı ve faşist hareketler ile Trumpizm’in simgelediği şey, aslında "küresel bir rejim değişikliği" talebiydi.

Böylelikle, düzenin kendisine ve kurumlarına olan halk desteği, neoliberalizmin özellikle Batılı ülkelerde halkla bağının kopmasıyla aşınırken, artık ekonomik koşulları giderek kötüleşen ya da en azından yerinde sayan Amerikalı orta sınıflar da sistemin "çarpık" (rigged) olduğu sonucuna vardılar (Colgan ve Keohane, 2017, s. 37). Bu da, var olan liberal yerleşik düzeni yıkmayı hedefleyen popülist, millici ve yerlici (nativist) hareketlerin yükselişine zemin hazırladı. Ancak bunların yıkmayı hedeflediği düzenin yerine neyi koyacağı da tam anlamıyla belli değildi. Daha ziyade burada, ülkelerinin geçmişte kalan büyüklük ve istikrar günlerine gönderme yapan hayli nostaljik bir arayış söz konusuydu (Ulagay, 2017, s. 13-14). Giderek belirsizleşen ve öngörülemeyen geleceğe dair ise, bu hareketlerin inandırıcı bir sözü ve çözüm vaadi pek yoktu.

Kısacası, gelişmiş ülkelerdeki sıradan insanlar neoliberal dönemde kapitalist sistemden tümüyle dışlandıkları, siyasi seçkinlerce unutuldukları ve ihmal edildikleri duygusuna kapıldılar. Günümüzdeki milliyetçi ve popülist dip dalganın gerisinde bu ihmal edilmişlik ve gelecek korkusu hislerinin payı büyüktür. Cohen’in (2016) ifadesiyle, "liberalizm ölmüştür. Ya da en azından ölüm döşeğindedir...hem dışarıdan hem içeriden artık kuşatma altındadır.”

Irak, Suriye ve Libya başta olmak üzere Arap Baharı ayaklanmaları sonrasında Kuzey Afrika ve Ortadoğu'da giderek kötüleşen insani durum ve Avrupa’ya yönelik sığınmacı akını ile birlikte, Avrupa'da ve ABD'de göçe ve göçmenlere yönelik popülist tepkilerin artması da liberal uluslararası düzeni sarsan ikinci gelişmeydi. Yukarıda da çözümlendiği üzere, Batı’daki krizin gerisindeki esas sebep neoliberal küreselleşme ve buna bağlı olarak izlenen ekonomik politikalar olmasına rağmen Batılı orta sınıf kitleler kendi refahlarındaki düşüşün sorumlusu sanki göçmenler ya da sığınmacılarmış gibi, göçmen/sığınmacı karşıtı ve yabancı düşmanı siyasi dalgaya teslim oldular. ABD’de beyaz nüfus oranı giderek düşerken beyaz olmayan göçmen nüfusun sayısındaki hızlı artış ülkenin elden gittiği korkusu ve paniği yarattı ki, bu, Trump’ın zaferinde önemli rol oynadı (Nye, 2017, s. 14-15). Mead'in (2017, s. 4) tespitiyle, ABD'de beyaz orta sinif, değerlerinin, kültürlerinin ve geleceklerinin ülkenin duyarsız ve kozmopolit elitleri ile düzensiz göçmenler 
yüzünden tehdit altında olduğu hissiyatıyla, bu değerleri koruma iddiasında bulunan ve liberal elitler ile göçmenleri açıkça hedef alan Trump’a ve onun popülizmine oy vermeyi tercih etmişti.

Üçüncü olarak, popülizmin yükselişinde ulusal egemenliğin ulus-üstü bütünleşmenin ve küreselleşmenin etkisiyle zayıfladığı düşüncesi ve algısı da etkiliydi. Özellikle AB bütünleşmesinin ekonomik krizle birlikte zora girmesi ve krize giren ülkelere dayatılan kemer sıkma politikaları bu ülke halklarında Birliğe yönelik tepkiye dönüștü. Avrupalılar, Niblett’in vurguladığı gibi, siyasal yönetim sistemlerini $\mathrm{AB}$ üyeliğiyle "ulus-devletten" "üye devlet" modeline taşımışlarken şimdi süreç tam tersine dönmekteydi (Niblett, 2017, s. 19). Dolayısıyla bugün mevcut ekonomik kriz ortamında Avrupa hükümetleri Brüksel’e daha fazla yetki devrinde iyice isteksiz hale geldikleri gibi, bütünleşme sürecinde devrettikleri bazı yetkileri de geri talep etmekteler. Son zamanlarda, başta İspanya ve Britanya olmak üzere ayrılıkçı ve bağımsızlıkçı hareketlerin yükselişi de, yine Avrupa bütünleşmesinin artık ulusal birliği/bütünlüğü dağıtan ve ulus-devlet modeline tehdit oluşturan bir yöne doğru evrildiği algısını güçlendirdi. Tüm bunlar da, AB’nin liberal bütünleşme modelinin artık dünyanın geri kalanı açısından esinlenilebilecek ve örnek alınabilecek bir model olma niteliğini zayıflattı (Niblett, 2017, s. 20). AB gibi uluslarüstü karakteri olmayan ama kriz anlarında hükümetlerin yardım talep ettiği IMF, Dünya Bankası ve DTÖ gibi çoktaraflı küresel yönetişim kurumlarının demokratik olmaktan uzak karar verme yapıları ve işleyişleri de, halkın gözünde bunların Batılı seçkinlerin çıkarlarını gözetmekten başka bir işe yaramadıkları algısına yol açtı (Colgan ve Keohane, 2017, s. 42).

Tüm bu faktörler üzerinde durulduktan sonra, bunların her birinde oynadığı rolden ötürü ABD’de liberal düzen karşıtı söylemiyle işbaşına gelen Başkan Trump’a değinmek yerinde olacaktır. ABD, Trump yönetimi altında artık liberal uluslararası düzenin koruyucusu ve kollayıcısı rolünü oynamak istemediğini, bu düzenin ilke, kural ve kurumlarını reddetme noktasına bile varan bir sertlikle ilan etti (Trump, 2017). Ancak ABD’nin düzenin altını oyan tutum ve davranışlarının Trump’n öncesine, Barack Obama ve George W. Bush dönemlerine kadar uzandığını burada belirtmek gerekir (Haass, 2017). Nitekim 11 Eylül sonrası siyasi iklimde Bush yönetiminin "terörle savaş" söylemini kullanarak Afganistan ve Irak’ı işgal etmesi ABD’nin artık kendini liberal değer ve ilkelerle bağlı saymadığının birer göstergesiydi (Duncombe \& Dunne, 2018, s. 27; Walt, 2018, s. 42). Bunlara ilaveten, 11 Eylül sonrası süreçte ABD’nin kendi vatandaşlarını dinleyip gözetleyen bir ulusal güvenlik devletine dönüşmesi, Guantanamo ve Ebu Garib cezaevlerinde işlenen işkence başta olmak üzere uluslararası suçlar, Kyoto Protokolü’ne karşı çıkış ve AntiBalistik Füze Antlaşması gibi uluslararası anlaşmalardan tek yanlı çekilme kararları (Jahn, 2018, s. 46), Bush ve özellikle Obama döneminde sayısı daha da artan SİHA’larla yargısız infazlar ve başta Orta Doğu olmak üzere terör örgütlerine verilen siyasi ve askeri destek gibi örnekler, ABD’nin kendi kurduğu düzene nasıl meydan okuduğunu fazlasıyla ortaya koymaktaydı (Walt, 2016). Mearsheimer’n (2019, s. 28) da vurguladığı gibi, ABD’nin Afganistan işgali tarihindeki en uzun askeri işgale dönüşmüş, Washington Misır'da 2013 yllında gerçekleşen asker darbeyi desteklemiş, Suriye ile Libyada başarısız rejim değişikliği politikaları izlemiş ve nihayet IŞiD terör örgütünün ortaya çıkışına neden olmuştu ki, bu haliyle de Soğuk Savaş sonrası dönemin evrensel karakterli bir liberal uluslararası düzen kurma çabaları boşa çıkmış olmaktaydı. Öyleyse, Trumpizm’in bu 
arka plan üzerinden değerlendirilmesine ve amacının da çoktan saldırı altındaki bu düzenin yıkılması ya da en azından ABD çıkarlarına uygun hâle getirilmesi olduğuna dikkat edilmelidir. Bu noktada, mevcut düzenin daha milliyetçi, devlet merkezli ve sorumluluk ile maliyetlerin daha adilane paylaşıldığı transaksiyonel bir düzene dönüştürülmesi gayreti gözlenmektedir. ABD, böylesi bir düzen içinde sadece kendi dar ulusal çıkarlarına ve özellikle de maddi çıarlarına odaklı bir dış politika izleyecek olup, bunun uluslararası düzenin işleyişine olası olumsuz etkilerini ise göz ardı edecektir (Patrick, 2017, s. 52).

Trump’nn bu düzen karşıtlığı, özellikle de serbest ticarete ve çok taraflılığa olan muhalefeti, ilk etapta ABD’nin iki savaş arası dönemdeki yalnızcılık politikasına geri dönüşü şeklinde yorumlansa da (Kühnhardt, 2017, s. 45), esasen Posen’ın (2018, s. 20) altını çizdiği gibi, Başkan Trump'in Amerikan hegemonyasından değil, bu hegemonyanın liberal karakterinden rahatsız olduğu iddia edilebilir. Benzer şekilde, Haass (2017), Peterson (2018) ve Chaudoin ve diğerleri (2018) de, Trump’n niyetinin yalnızcılık politikasına geri dönmek değil, liberal düzenin lideri olmaktan ve bunun getirdiği sorumluluklardan "vazgeçmek ya da çekilmek" (abdication) olduğu iddiasındadır. Haass’ın ifadesiyle, “Trump, dünya liderliğinin getirdiği yüklerin faydalarını aştığı görüşüne sahip olan İkinci Dünya Savaşı sonrasındaki ilk Amerikan başkanıdır. Sonuç olarak, Birleşik Devletler düzenin başlıca koruyucusundan başlıca düzen bozucusuna dönüşmüştür” (Haass, 2017). Dolayısıyla, geçmişte partiler üstü bir anlayışla sürdürülen pax-Americana bugün Trumpizm tarafından liberal özelliklerinden arındırılmaktadır. Bu bakımdan, Trump’n liberal demokrasinin yayılması hedefini de gözetmeksizin Amerikan üstünlügünü savunarak bunun devamını sağlamaya çalıştığı açıktır. Hatta ABD’nin Trump yönetimi altındaki yeni büyük stratejisinin, liberal olmayan (illiberal) bir hegemonya olduğu bile bu noktada savunulabilir. Trump yönetiminin, ülke dışında askeri maceralara girmeme söylemine rağmen askeri operasyonlarına tüm dünyada (Suriye'de IŞİD ile mücadele ya da Nisan 2017'de Esad güçlerine karşı füze saldırısı örneğindeki gibi) devam ettiği, büyük güçlerle rekabet odaklı bir ulusal güvenlik stratejisi benimsediği, Pentagon bütçesini ciddi biçimde artırdığı ve pek çok ülkeyi ekonomik ve siyasi yaptırımlarla tehdit ettiği dikkate alındığında, bu görüşe hak vermemek mümkün değildir. (Haass, 2017; Posen, 2018, s. 20-21)

Böyle bir ortamda, Trump, "Önce Amerika” söylemi (Kagan, 2017) doğrultusunda liberal ticaret kurallarına, çok taraflılığa, iklim değişikliğine ve geleneksel ittifaklara karşı duran ve insan hakları gündemi de bulunmayan, hatta açıktan işkenceyi savunan bir yönelimle seçimlerden galip çıktı (Haass, 2017). İşbaşına gelir gelmez Pasifik coğrafyasındaki ABD dâhil 12 ülke arasında kapsamlı bir serbest ticaret anlaşmasını öngören Trans-Pasifik Ortaklığı’ndan çekilme kararı alan Trump’n bizzat tarihteki en kötü anlaşma diye nitelediği Kuzey Amerika Serbest Ticaret Anlaşması NAFTA’yı da sorguladığı görülmekteydi (Peterson, 2018, s. 28). Yine AB ile ABD arasında 2013'ten beri müzakereleri devam eden Transatlantik Ticaret ve Yatırım Ortaklı̆̆ projesinin akıbeti de belirsizliğe sürüklendi (Kühnhardt, 2017, s. 51). Nitekim ABD’de TransPasifik Ortaklığı'na, Avrupa'da ise Transatlantik Anlaşması’na yönelik artan halk tepkileri ve kitlesel protestolar da bu iki iddialı girişimin olumlu sonuçlanmasını zorlaştırmıştı (Niblett, 2017, s. 19). ABD’nin 2015’te Paris’te imzalanan çoktaraflı İklim Sözleşmesi’nden Kasım 2019 
itibarıyla resmen çekilmesi de, Trump’ın hem iklim değişikliğine hem de çoktaraflı düzenlemelere karşıt tutumuna uygun bir adımdı (Haass, 2017). Nitekim Trump da bu çekilmeleri BM Genel Kurulu’nda Eylül 2018'de yaptığ 1 konuşmada şu sözlerle gerekçelendirmekteydi: “Tüm dünyadan yabancı mallar ABD’ye serbest bir şekilde geliyordu. Fakat diğer ülkeler bu hakkı bize tanımadılar. Artık hiçbir ülke ABD'den tek taraflı yararlanamayacak. Bazı ülkeler bize karşı haksız avantaj elde ettiler. Bu bağlamda yüzlerce milyar dolar ticaret açığı yaşadık. Kötü ticaret anlaşmalarından çıktık" (Bloomberght, 2018). Buradan da anlaşılabileceği üzere, Trump yönetiminin küreselleşme, küresel sorunlar, küresel yönetişim ve insan hakları gibi bir gündemi bulunmadığı açıktı.

Trumpizm’in küreselleşme karşıtı retoriği ve adımlarının kazananının ise, küreselleşmenin özellikle de açık ve serbest ticaret rejiminin yeni sahipliğine ve savunuculuğuna soyunan Çin olduğu söylenebilir (Hu ve Spence, 2017, s. 54-55). Nitekim Çin Devlet Başkanı Jinping 2017'de Davos'taki Dünya Ekonomi Forumu toplantısında Trump’n ABD'yi hegemonik liderlikten çekmesi halinde kendi ülkesinin küreselleşmeyi, serbest ticareti ve iklim değişikliği ile mücadeleyi savunacağını açıkça ifade etmişti (Parmar, 2018, s. 169; Peterson, 2018, s. 34; Ulagay, 2017, s. 11). Aynı şekilde Brexit oylaması da, küreselleşme karşıtlı̆̆ının referandumda AB karşıtı bir noktaya evrilerek Birleşik Krallık’n yarım asra yaklaşan üyelik sürecinin sonuna gelmesine yol açtı. $\mathrm{Hu}$ ve Spence'in (2017, s. 56) ifadesiyle, “...Brexit’ in küreselleşme karşıtllğı, yerlicilik ve milliyetçilik açısından bir zafer anlamına geldiğine kuşku yoktur." Bu noktada Brexit sürecinde AB’den çıkışı savunan Bağımsızlık Partisi lideri Nigel Farage ile Trump’n kendisi ve ekibi arasındaki yakınlık ile yine Trump’nn ve yakın çevresinin Fransa’daki cumhurbaşkanlığı seçimlerinde aşırı sağı temsil eden Ulusal Cephe lideri Marine Le Pen’e açık desteği de, küreselleşme karşıtı platformun ortak bir gündem etrafında bir araya geldiğini göstermekteydi.

Ikenberry, 2018'deki makalesinde (s. 8) liberal düzenin Amerikan hegemonyasından daha uzun ömürlü olacağını, zira Batılı ülkeler kadar yükselen güçlere de fayda sağladığını savunur. Bugünkü kriz de, esasında liberal düzenin değil, bu düzenin kurucusu ve koruyucusu ABD’nin kendi hegemonik krizidir (Jahn, 2018, s. 43). Bu bakımdan liberalizmin günümüzdeki krizi daha az değil, aksine daha fazla liberalizm ile çözülecektir. Hirsch (2019) de, Ikenberry gibi, liberal düzenin ve onun sacayakları olan demokrasi, küreselleşme ve serbest ticaretin $2020^{\prime}$ lerde karşılaştı̆̆ tüm meydan okumalardan sağ çıkacağı ve bu on yıla da alternatifsiz bir dünya görüşü olarak hâkim olacağı inancını taşımaktadır. Aşağıda, bu iyimser beklentinin ne kadar gerçekçi olduğu çözümlenmektedir.

\section{Liberal Uluslararası Düzenin Bir Geleceği Var mı?}

Son dönemde küreselleşme karşıtı ve liberalizme düşman milliyetçi/yerlici eğilimlerin yükselişi ile kendini gösteren "küreselleşme saatini geriye alma" yönündeki çabalar, liberal uluslararası düzenin devamlılığı ve dayanıklılığı açısından artık ciddi bir sınamaya dönüşmüştür. Korumacilık, popülizm ve milliyetçilik kitleleri şu anda peşinden sürüklese de, bunların geçmişte olduğu gibi küresel istikrar ve güvenliği tehlikeye atması da pekâlâ mümkündür (Hu ve Spence, 2017, 
s. 63). Karim (2017, s. 68) ise, popülizm ile küreselleşme karşıtlığının liberal düzenin devamı için birer tehdit değil aksine uyarı olduğu ve bu uyarıların dikkate alınarak liberal demokrasinin kusurlarının giderilmesi halinde söz konusu düzenin ayakta kalabileceğini savunur. Mevcut liberal düzenin devamı noktasında ise, iki farklı seçenekten söz etmek mümkündür: küreselleşmeye sahip çıkacak ve düzen kurma iddiası bulunan yeni bir lider ülke/ulus arayışı ile liberal düzenin reformdan geçirilerek kusurlarının giderilmesi.

İlk seçenekle başlamak gerekirse, şu soruyu sormak mantıklı olacaktır: ABD’nin başkanlık düzeyinde liberal uluslararası düzenin ilke, kural ve normlarını sorguladığı bir ortamda bu düzenin yeni bir lidere ihtiyacı var mıdır, varsa bu lider kim olacaktır? Batı, Batılı olmayan bir aktörün iradesinin şekillendireceği bir düzeni kabullenmeye hazır mıdır? Trump yönetimi altında ABD’nin liberal uluslararası düzene liderlik etmenin maliyetinin faydasını fazlasıyla aştığı görüşünde olduğu ve diğer ülkelerle ilişkilerinde sadece kendisinin kazanan durumunda olacağ 1 iki taraflı (dyadic) bir ilişki biçimini tercih ettiği açıktır (Nye, 2017, s. 12). ABD’nin mevcut liberal düzeni sorguladığı böyle bir ortamda, Çin’in küreselleşmenin yeni sözcüsü ya da sahibi gibi davranmaya başlaması şaşırtıcı değildir. Nitekim Davos’taki 2017 Dünya Ekonomik Forumu zirvesinde söz alan Çin Devlet Başkanı Jinping serbest ticareti ve küreselleşmeyi savunmaktan geri durmadı. Eylemleriyle de daha kapsayıcı ve çoktaraflı bir küreselleşme sürecine desteğini ortaya koyan Çin yönetimi, bu doğrultuda Asya Altyapı Yatırım Bankası, Kuşak ve Yol projesi ve Yeni Kalkınma Bankası gibi girişimleriyle öne çıktı. Bunlardan Kuşak ve Yol projesi Çin'in "alternatif küreselleşme” girişimi olarak yorumlandı (Küçükcan, 2017, s. 86). Başkan Trump’ın Eylül 2018'de BM Genel Kurulu’na hitaben “ABD, Amerikalılar tarafından yönetilir. Biz küreselleşme doktrinini reddediyoruz. Tüm dünyadaki ülkeler kendi ülkelerini korumalıdır" (Bloomberght, 2018) ifadelerini kullanması üzerine, Çin’in bu küreselleşme savunuculuğu daha da önem ve anlam kazandı. Ancak ABD’nin bıraktığı boşluğu doldurma istek ve kararlılığı dikkat çekse ve dünyanın en azından satın alma gücü paritesiyle en büyük ekonomisi konumuna yükselse de, Çin'in yeni liderlik iddiasının içini ekonomik ve siyasi manada doldurması ve bunun gerektireceği sorumluluğu üstlenip üstlenemeyeceği hâlâ bir soru işareti oluşturmaktadır. Ikenberry’nin (2018, s. 17) ifadesiyle, "Çin muhtemelen liberal olmayan bir hegemon olarak Birleşik Devletler'in yerini almayacak...Fakat ABD - ve eski müttefikleri - küresel bütünün daha küçük bir parçası olmaya devam edecekler ve bu onların liberal uluslararası düzeni destekleme ve savunma yeteneklerini sinirlandiracak."

Çin bir hegemon güç olamasa bile siyasi olarak tek parti yönetimi altında vatandaşlarına temel insan haklarını ve özgürlüklerini sağlamaktan uzak bir anlayışla (Dams ve van der Putten, 2015, s. 5) küreselleşmeyi yalnızca ticari ve ekonomik boyutuyla sahiplenme iddiası gütmektedir. Ancak Çin'in 2001'deki DTÖ üyeliği de, ülkenin uluslararası ticaret sistemi kurallarını istismar etmesinden dolayı ekonominin daha fazla serbestleşmesi ile sonuçlanmamıştır (Dworkin ve Leonard, 2018, s. 14). Çin'in liberal düzenle kurduğu pragmatik ilişkiye atfen Dams ve van der Putten $(2015$, s. 13) şu tespitte bulunmaktadır: "Çin liberal uluslararası düzenle liberal ideolojiyi paylaştı̆̆g için değil, Çin’in ihtiyaçlarına hizmet ettiği için bütünleşiyor.” Bu noktada Çin yönetiminin, gerek kendi işgücünü acımasız koşullar altında çalışmaya zorlayan gerekse de ülkesindeki Uygurlar gibi farklı etnik ve 
Tibetli Budistler gibi farklı dini kökenden gelenlere yönelik ayrımcı ve baskıcı politikalarından dolayı başta ABD olmak üzere Batılı liberal ülkelerin eleştirileri ile karşı karşıya kaldığı görülmektedir. Amerikan liberallerinin Çin'in ekonomik kalkınmasının zamanla siyasi olarak demokratikleşmesi ile sonuçlanacağına yönelik beklentileri ise gerçekleşmemiştir (Karan, 2020). ABD eski Dişişleri Bakan yardımcısı Zoellick'in 2005'te Çin’i liberal düzenden yararlanırken "sorumlu bir paydaş" gibi hareket etmeye çağırmasının üzerinden 15 yl geçtikten sonra, bugün ise Trump yönetimindeki ABD’ye sorumlu bir paydaş gibi davranmadığı suçlaması yöneltilebilmektedir (Patrick, 2020). ABD ve Batı́nın Çin ekonomisinde devletin rolü ve ağıllı̆ııı azaltma ile Çin’i insan haklarına saygılı demokratik bir rejime dönüştürme arayışı başarılı olamamıştır. ABD ile Çin’in küreselleşmeden ve küresel yönetişimden anladıkları giderek birbirinden farklılaşmıştır. Çin, "Beijing Uzlaşısı" (the Beijing Consensus) diye bilinen kendi modelinin de meşru bir kalkınma yolu olduğu iddiası ile Batı tarzı liberalizmin zorunlu tek kalkınma yolu olduğuna karşı çıkmaktadır. Ancak bu tablo, Çin’in küreselleşmenin sadece bir boyutunu benimserken diğer boyutlarını ise yok saydığı ya da bunlara saygı duymadığı bir ülke imajına yol açmaktadır. Çin bu haliyle, hegemon gücün diğerleri tarafından örnek ya da model alındığı bir ülke portresi ise çizememektedir. Dolayısıyla, tek parti yönetimi altında belli ölçüde bir kalkınma başarısı gösterse de, insan hakları ve özgürlüklere ilişkin bu yaklaşımı Çin’in zayıf karnı olup küresel liderlik iddiasının karşısındaki en önemli engellerden biridir. ABD ve Batı açısından daha kötüsü ise Çin’in artan gücünü uluslararası düzlemde liberalizmi zayıflatmak için kullanmaya kalkmasıdır ve hatta bazılarına göre Beijing çoktan bunu yapmaya başlamışıtır (Dams ve van der Putten, 2015, s. 6). Çin, Batılı liberal uluslararası düzenin karşısına doğrudan komünist ideolojisiyle dikilmese de, küresel yönetişime yönelik pragmatik yaklaşımı ve demokrasi ile insan hakları gibi liberal değerlerin tüm dünyada yayılmasına karşı duruşu, onu liberal Batı ile karşı karşıya getirmektedir.

Çin'in, İkinci Dünya Savaşı sonrası ABD’ninkine benzer bir liderlik rolüne soyunmasının önünde başka ciddi engeller de vardır. En başta Çin, henüz ihracata dayalı bir ekonomiden yüksek iç tüketime ve yatırıma dayalı bir modele geçiş sürecini tamamlayamamıştır ve ABD gibi bir kriz anında yüksek iç tüketimle dünya ekonomisini destekleyebilecek durumda değildir. 12 trilyon doları aşan büyüklüğüne rağmen ekonominin yavaşlayan büyüme oranının yanı sıra, yüksek özel sektör borcu, aşırı kapasite, yeterince açık ve derinleşmemiş sermaye piyasaları gibi önemli sorunları bulunmaktadır. Yine Çin, son dönemde para birimi Yuan’’ uluslararasılaştırma yönündeki adımlarını da, ülkeden sermaye çıkışını durdurmak amacıyla sermaye kontrollerini artırarak yavaşlatmış durumdadır (Hu ve Spence, 2017, s. 60). Jinping iktidarını giderek merkezileştirip gücü tek elde toplarken, bunun gerisindeki saik ise, Çin Komünist Partisi’nin ekonomik dönüusüm sürecinde içerden ve dışardan gelebilecek baskı ve tehlikelere karşı güçlü kalabilmesini sağlamaktır. Yine Jinping'in Çin’deki Batı kültürü etkisini zayıflatmak istediği ve bunu yolsuzlukla mücadele örtüsü altında yapmaya çalıştığı da ileri sürülmektedir (Niblett, 2016). Bu açıdan bakıldığında, ekonomik küreselleşmeyi sahiplense de, liberalizme açıkça düşman olan Çin’in Batı dünyasında yükselen milliyetçi/yerlici nostaljik eğilimlere paralel bir çizgiye kayması ihtimal dışı değildir. $\mathrm{Bu}$ yönleriyle Çin’in, diğer ülkelerin de çıkarına olacak kurallar ve normları belirleyecek bir lider veya düzen kurucu ülke rolü oynaması muhtemel görünmemektedir (Haass, 2017). 
Çin bir yana bırakılırsa, liberal uluslararası düzeni kurtarma arayışında Avrupa bir rol üstlenebilir mi? Trump’ın 70 yıllık transatlantik ilişkilere zarar veren tutumu karşısında liberal uluslararasıcıllğ̆ savunanların tek umudu olarak geriye AB kalmış görünmektedir (Dworkin ve Leonard, 2018). Ancak küresel jeopolitikte aktif ve etkili bir oyuncu olmak bir yana, durağanlığa sürüklenen ve hatta fetret devrine girmiş olan dağınık görünümüyle (Ülger, 2019) AB, giderek sertleşen Çin ile ABD arasındaki jeopolitik rekabetin ortasında kalmış görünmektedir (Hatip, 2020). Bu noktada, özellikle Macron liderliğindeki Fransa ile Merkel'in Almanyası'nın liberal düzenin ABD’nin elinden kurtarılması rolüne soyundukları söylenebilir. Nitekim Dworkin ve Leonard (2018, s. 2-3,23) Trump yönetimini liberal uluslararası düzene yönelik bir tehdit olarak niteleyip AB’nin ABD’nin düzenin savunuculuğu noktasında bıraktığı bu boşluğu doldurabileceğini ve hatta doldurmak zorunda olduğunu iddia etmektedir. İkiliye göre, liberal düzenin korunması Birliğin küresel stratejisinin merkezine konulmalı ve $\mathrm{AB}$ bu yeni düzen savunuculuğu rolünü oynarken demokrasi, insan hakları ve çoktaraflılığa bağlılık gibi ilkelere mutlaka sahip çıkmalıdır. Zira bu ilkeler ve onların savunulması AB’nin ekonomik ve siyasi çıkarlarının bir gereğidir. Bunu yaparken Birliğin söz konusu düzenin eksik ve kusurlu yönlerini de göz önüne alarak bunları bertaraf etme ve düzenin devamına ilişkin kurala dayalı yeni bir vizyon sunma yükümlülüğü bulunmaktadır. Avrupa bugünlerde ABD’ye karşı bir yandan savunma ve güvenlik alanında özerklik arayışı içine girerken diğer yandan küreselleşmeyi savunma noktasında Çin ile işbirliğine de artık soğuk bakmamaktadır. (Kirchick, 2018) Nitekim AB, DTÖ kurallarına bağlı kalma ve 2015 Paris İklim Sözleşmesi'ni uygulama konularında Çin ile mutabakat halindedir. Yine AB, yakın zamanda Japonya ve MERCOSUR (Güney Amerika Ortak Pazarı) ile yaptığına benzer bir serbest ticaret anlaşmasını Çin ile de yapmaya hazırlanmaktadır.

Ancak öte yandan, Avrupa da, yaşanan krizin aslında Amerikan hegemonyasının krizi olmaktan ziyade liberalizmin krizi olduğunu gösteren gelişmelerle başa çıkmakta zorlanmaktadır. Özellikle popülist, aşırı milliyetçi ve yabancı düşmanı akımların kimi Avrupa ülkelerinde iktidara gelme ya da iktidar ortağı olma şanslarının artması AB’nin üzerine kurulduğu liberal değerleri tehdit etmektedir. Bunun ise, kıtayı bir "kale Avrupa"ya (Fortress Europe) dönüştürerek, içe kapanma ya da daha kötüsü $A B$ ’nin parçalanması endişelerini artırdığı gözlenmektedir (Webber, 2018). Hatta AB’nin son on yılını, 2010-2012 Euro krizi, 2014 Ukrayna Krizi, 2015 Göçmen Krizi ve 2016 Brexit referandumu sonucu Birleşik Krallık’n AB'den ayrılma kararı alması gibi üst üste yaşanan krizlerle dolu geçirdiğini tespit eden Webber (2014), esas olarak ise yukarıda bahsi geçen iç faktörlerin ve siyasi dinamiklerin Birliğin parçalanmasında tahmin edilenden daha fazla rol oynayabileceği görüşündedir. $A B$ halklarının geçmişte Avrupalı elitlerin $A B$ bütünleşmesini kapalı kapılar ardında şekillendirmesine ses çıkarmadığı dönemler artık geride kalmış olup, bugün üye devletlerde yukarıdaki krizlerin de etkisiyle bütünleşmeye şüpheyle bakanların ve karşı çıkanların siyasi güçlerini ve etkilerini giderek artırdıkları bir döneme geçilmiştir. Webber (2014, s. 352) bunu, müsamahakâr uzlaşıdan (permissive consensus) müsamahasız anlaşmazllğa (unpermissive dissensus) doğru bir geçiş olarak niteler. Trump yönetiminin bu tür akımlara ve Birliğin parçalanmasına verdiği açı destek de, transatlantik ittifakın eski günlerinden çok uzak olduğunun bir işareti durumundadır. Dolayısıyla AB’nin öncü ülkelerinde liberalizme 
siyasi bağll1ı sürse de, kita genelinde bu konuda bir mutabakattan ve AB’nin liberal değerlerin tek başına koruyuculuğunu üstlenmeye soyunabileceğinden söz etmek bu koşullarda mümkün görünmemektedir. Maull'un (2019, s. 3) tespitiyle, dış politikada sivil güç (civilian power) olarak anılan AB’nin "dünya siyasetini "medenileştirme" veya dönüştürme hırslarında başarılı olmalarının giderek” zorlaştığı bir küresel düzensizlik hâli söz konusudur.

Liberal uluslararası düzenin geleceği tartışması bağlamında sorulması gereken ikinci hayati soru da şudur: Küreselleşmenin kazanımlarını koruyabilecek reformların yapılması ve liberal uluslararası düzenin kusurlarının giderilmesi mümkün olabilecek mi? Bu noktada, kimi analistler mevcut düzene yeni bir lider aramak yerine doğru ve kararlı siyasi reformlar yoluyla düzenin yeniden toparlanabileceği görüşündedir. Sözgelimi Niblett (2016), politikacıların doğru adımları atması halinde mevcut kriz durumunun önüne geçmenin ve liberal uluslararası düzeni kurtarmanın mümkün olabileceğine inanmaktadır. Aksi bir durum ise, dünyayı hem devletlerin içinde hem de arasında olmak üzere tekrar sürtüşmeli ve çatışmalı bir döneme sürükleme riski taşımaktadır. Yine Dünya Ekonomik Forumu’nun başındaki Klaus Schwab da Ocak 2019'daki Davos toplantısında İkinci Dünya Savaşı sonrası yapılan konferanslara benzer yeni bir konferans toplanması çağrısında bulunmuştur. 2008-2009'daki Küresel Mali Krizden beri bu tür çağrılar yapılmaktadır ve bununla amaçlanan da dünyaya yeniden bir düzen vermektir.

Liberal uluslararası düzeni savunanlardan Mallaby (2016), küreselleşmenin yarattığı eşitsizliğe ve gelir dağılımındaki bozulmaya çarenin serbest ticareti kıstllayıp daha fazla korumacılığa geçmek olmadığına dikkat çekerek, esas sorunun doğru politikaları geliştirip izleyemeyen hükümetler olduğu iddiasındadır. Bu çerçevede, ulusal hükümetler, vergi ve harcama politikaları aracılı̆̆ılla aslında refahın yeniden ve daha adil dağıtımını sağlayabileceklerdir. Bunu yapamamaları halinde ise sorumluluk hükümetlerin olacaktır. Niblett (2016) de, küreselleşmenin yarattığı sorunlar karşısında gerek gelişmiş gerekse de gelişmekte olan dünyada hükümetlerin etkin bir vergi sistemi, e-devlete geçiş, yolsuzlukla mücadele, enerji altyapısının modernleştirilmesi, eğitime yatırım yapılması ve herkese sağlık hizmet sağlanması gibi adımları atarak ulusal yönetişim yapılarının niteliğini artırmaları gerektiğini kaydeder. Dolayısıyla, 21. yüzyılda küreselleşmenin yol açtığ sorunlar karşısında liberaller devleti yardıma çağırmaktan başka bir çözüm önerememektedir.

Peki, ulusal hükümetlerin böyle bir niyeti var mıdır? Ikenberry (2018, s. 23), ABD başta olmak üzere Batılı liberal demokrasilerin, geçmişteki gibi yeniden ilerlemeci (progressive) bir siyasal yönelimle sadece piyasaya fayda sağlayan neoliberal politikaları daha Avrupa tipi sosyal demokrat olanlarla değiştirip değiştirememelerini, liberal düzenin devamı ve geleceği için hayati görmektedir. Oysa ABD örneğinde, Trump yönetimi Obama’nın sağlık reformu yasasını iptal etme ve vergi indirimi yapma misyonuyla işbaşına gelmiştir. Ancak uygulamada görevde birinci yılını doldururken başkan Obama döneminde çıkarılan sağlık reformunu ortadan kaldırma girişimi başarılı olamamış, vergi reformu vaadi ise geleneksel Cumhuriyetçi politikalara uygun olarak şirketler için avantaj sağlayacak şekilde çıkmıştır (Özel, 2017). Üstelik iptal edilemeyen sağlık reformu düzenlemesinin 13 milyon Amerikan vatandaşına sigortalı olma imkânı veren kısımlarının 2027’ye kadar ortadan kaldırılmasını sağlayacak bir değişiklik de vergi reformu 
yasasına eklenmiştir. Vergi reformu ile Trump'ın asıl hedefi ise, kendisine oy veren orta sınıf kitleleri rahatlatmaktan ziyade ekonomiyi canlandırmak adına Cumhuriyetçi Parti’nin çizgisine uygun olarak en zengin üst gelir grubu kesimlere ve şirketlere yönelik büyük vergi indirimleri getirmekti (Özel, 2017; Sachs, 2017; Time, 2017). Nitekim bu reformun üzerinden iki yıl geçtikten sonra vergi indirimlerinin reform öncesine göre çok daha düşük oranda vergi ödeyen Amerikan şirketlerinin rekor kâr yazmalarını sağladığı açıç̧a görülmekteydi (Reich, 2019). Reich (2019), Cumhuriyetçi Parti’yi büyük şirketler ve Wall Street'in çıkarlarını temsil eden bir parti olmaktan işçi sınıfının sesi olan bir parti olmaya doğru dönüştürdüğü iddiasındaki Trump’in 2020 başkanlık seçimleri yaklaşırken mevcut vergi indirimleri ile de yetinmeyip daha fazla vergi indirimi yapmayı planladı̆̆ına dikkat çekmektedir. Bu ise, sadece şirket kârlarının şişmesine değil aynı zamanda federal bütçe açı̆̆ının artmasına da yol açacaktır. Trump’’n özellikle Çin mallarına karşı getirdiği yüksek tarifelerin ABD’deki mal fiyatlarını artırarak ve üretim maliyetini yükseltip işsizliğe neden olarak Amerikan işçilerine iki yönlü bir zarar vermesi de cabasıdır. Bunların haricinde, Trump yönetiminin pek çok yoksul Amerikan vatandaşını olumsuz etkileyecek bir kararla gıda yardımlarında 4,5 milyar dolarlık kesinti yapması ile bazı sosyal güvenlik harcamalarında kesintiye gitmesi de kendisine oy veren kitlenin çıkarına aykırı diğer adımlar olarak kaygı vericidir (Reich, 2019).

\section{Sonuç}

Liberal uluslararası düzenin kuruluşu ve gelişimi pax-Americana'dan ne kadar bağımsız düşünülemez ise söz konusu düzenin bugünkü krizi de sadece ABD’nin kendi hegemonik krizi olarak açıklanamaz. Nitekim meselenin bundan daha öte ve derin boyutları olduğu bu çalışmada ortaya konulmuştur. Liberallerin öne çıkardığ liberal düzenin kendi başarısının kurbanı olarak geçici bir krize girdiği ve bundan da eninde sonunda sağ salim çıkacağı çözümlemesi, meselenin daha derin ve çözümü zor bir karakteri olduğunu görmezden gelmektedir. Liberal uluslararası düzenin olası ve korkutucu alternatifleri arasında, liberalizmden uzak, kapalı ve bölgesel olarak korumacı bloklardan oluşan bir dünya öne çıkmaktadır. Böyle bir dünyada bloklar arasında sürtüşme ve hatta çatışma ihtimalinin artması söz konusu olabilecektir. Bu çatışma, İkinci Dünya Savaşı sonrası olduğu gibi sıcak bir çatışmaya dönüşmeden ideolojik mücadele ve rekabet şeklinde olabileceği gibi; 1930’lu yıllar örneğinde görüldüğü üzere, küresel güçler arasında sıcak bir çatışma şeklinde de tezahür edebilecektir. 2020 itibarıyla bakıldığında AB ile ABD arasındaki transatlantik bağların giderek gevşediği ve hatta sarsıldığı bir dönemden geçilirken ABD ile Çin arasındaki ilişkilerin de Trump döneminde gerginleşmesi ile birlikte iki güç arasında bir soğuk savaş ihtimalinin giderek kuvvetlendiği yorumları yapılmaktadır.

Öte yandan, ideolojik olarak da liberalizme tutarlı bir alternatif henüz ufukta belirmemiştir. ABD Trump yönetiminde liberalizme düşman, Çin liberalleşmekten çok uzak ve liberalizmin ayakta kalan tek kalesi sayılan $\mathrm{AB}$ de düzen kurucu bir role soyunma yeteneğinden yoksun görünmektedir. $\mathrm{Bu}$ aktörlerin her üçünün de karşısında düzen kurma yeteneklerini ve kapasitelerini kısıtlayan iç sorunlar ve engeller bulunmaktadır. ABD’de siyasetin kutuplaşması ve işlevsizleşmesi ile 
popülizmin yükselişi, Avrupa’da bütünleşmeye olan inancın azalarak bütünleşme karşıtı popülist hareketlerin ve akımların güçlenmesi ile Çin'de ekonomideki yapısal sorunlara ilaveten etnik ve dinsel azınlıklara yönelik insan hakları ihlalleri düzen kurucu potansiyeli olan bu aktörleri zorlamakta ve kısıtlamaktadır. Ne Çin'in otoriter kapitalistleşme modeliyle ne de AB’nin sarsıntı geçiren ulusüstü bütünleşme modeliyle diğer uluslara esin kaynağı olmaları zordur. Yine bu gibi güçlerin yeni bir dünya düzeni kurulmasına liderlik etme kapasiteleri de birçok açıdan şüphelidir. ABD başta olmak üzere popülist politikalara meyleden Batının ve onun yönetici elitlerinin ise, bu düzeni ayakta tutacak ne kapsamlı ve köklü iç reformlar yapmaya ne de temsil gücü daha yüksek bir uluslararası düzeni kabul etmeye niyeti bulunmaktadır. Tüm bu tablo karşısında, yeni düzenin, liderini/mimarını bulana ya da Batı’da güçlü bir ilerici reform iradesi oluşana kadar daha az liberal ve daha az Amerikan karakterli bir hâle bürüneceği, düzenin geleceğine yönelik yapılabilecek en makul öngörü olarak durmaktadır.

\section{Kaynakça}

Alcaro, R. (2018). “The Liberal Order and Its Contestations: A Conceptual Framework”, The International Spectator, 53(1): 1-10, https://doi.org/10.1080/03932.729.2018.1397878.

Bloomberght, (2018). “Trump: Küreselleşme doktrinini reddediyoruz",https://www.bloomberght.com/ haberler/haber/2158687-trump-kuresellesme-doktrinini-reddediyoruz, 25 Eylül, accessed on 23.01.2020.

Chaudoin, S., Milner, H. V., Tingley, D. (2018). “Down But Not Out: A Liberal International American Foreign Policy”, In R. Jervis, F. Gavin, J. Rovner, D. N. Labrosse (Eds.), Chaos in The Liberal Order: The Trump Presidency and International Politics in The Twenty-First Century, New York: Columbia University Press, 61-97.

Cohen, R. (2016). “The Death of Liberalism”, The New York Times, 14 April, https://www.nytimes. com/2016/04/14/opinion/the-death-of-liberalism.html, accessed on 24.04.2019.

Colgan, J. D. and Keohane, R. O. (2017). “The Liberal Order is Rigged”, Foreign Affairs, 96(3): 36-44.

Cox, M. (2019). "Nationalism, Nations and The Crisis of World Order", International Relations, 33(2): $247-$ 266, https://doi.org/10.1177/004.711.7819842306.

Dams, T. and van der Putten, F. T. (2015). “China and Liberal Values in International Relations”, Clingendael Report, Netherlands Institute of International Relations, https://www.clingendael.org/sites/default/ files/pdfs/China_and_Liberal_Values_in_International_Relations.pdf, accessed on 10.06.2020.

Duncombe, C. \& Dunne, T. (2018). "After Liberal World Order”, International Affairs, 94(1): 25-42, doi: 10.1093/ia/iix234.

Dünya Eşitsizlik Raporu 2018, (2018). https://wir2018.wid.world/files/download/wir2018-summaryturkish.pdf, accessed on 12.06.2020.

Dworkin, A. and Leonard, M. (2018). “Can Europe Save the World Order?", European Council on Foreign Relations, Policy Brief, https://www.ecfr.eu/page/-/can_europe_save_the_world_order.pdf, accessed on 11.06.2020.

Frankel, J. (2000). “Globalization of the Economy”, In J. S. Nye Jr. \& J. D. Donahue (Eds.), Governance in a Globalizing World, Washington D.C.: Brookings Insitution Press, 45-71.

Glaser, C. L. (2019). “A Flawed Framework: Why the Liberal International Order Concept is Misguided”, International Security, 43(4): 51-87, https://doi.org/10.1162/isec_a_00343. 
Haass, R. (2017, December 28). "America and The Great Abdication", The Atlantic, https://www.theatlantic. com/international/archive/2017/12/america-abidcation-trump-foreign-policy/549296/, accessed on 12.06.2019.

Haass, R. (2017, Jan/Feb). “World Order 2.0.", Foreign Affairs, 96(1): 2-9.

Hatip, Y. (2020). “AB’nin Kısır Dış Politikası Küresel Etkisini Zayıflatıyor”, Anadolu Ajansı, 08 Ocak, https:// www.aa.com.tr/tr/analiz/abnin-kisir-dis-politikasi-kuresel-etkisini-zayiflatiyor-/1695934, accessed on 12.01.2020.

Hirsch, M. (2019). "Why The Liberal International Order Will Endure into The Next Decade”, Foreign Policy, 27 December, https://foreignpolicy.com/2019/12/27/why-liberal-international-order-willendure-next-decade-2020-democracy/, accessed on 12.01.2020.

Ikenberry, G. J. (2009). "Liberal Internationalism 3.0: America and The Dilemmas of Liberal World Order", Perspectives on Politics, 7(1): 71-85, doi:10.1017/S153.759.2709090112.

Ikenberry, G. J. (2010). “The Liberal International Order and Its Discontents”, Millennium: Journal of International Studies, 38(3): 509-521, https://doi.org/10.1177/030.582.9810366477.

Ikenberry, G. J. (2011). Liberal Leviathan: The Origins, Crisis, and Transformation of the American World Order, Princeton: Princeton University Press.

Ikenberry, G. J. (2017). “The Plot against American Foreign Policy: Can The Liberal Order Survive?”, Foreign Affairs, 96(3): 1-7.

Ikenberry, G. J. (2018). “The End of Liberal International Order?”, International Affairs, 94(1): 7-23, doi: 10.1093/ia/iix241.

Ikenberry, G. J., Mastanduno, M., Wohlforth, W. C. (2009). “Introduction: Unipolarity, State Behavior, and Systemic Consequences”, World Politics, 61(1): 1-27.

Jahn, B. (2018). "Liberal Internationalism: Historical Trajectory and Current Prospects", International Affairs, 94(1): 43-61, doi: 10.1093/ia/iix231.

Jervis, R. (2009). “Unipolarity: A Structural Perspective”, World Politics, 61(1): 188-213.

Kagan, R. (2017). “The Twilight of The Liberal World Order”, Brookings Institution Report, 24 January, https:// www.brookings.edu/research/the-twilight-of-the-liberal-world-order/, accessed on 29.09.2019.

Karan, C. (2020). “Gelişmeler ABD-Çin Soğuk Savaşını Andırıyor, Pekin AB’yi ABD’ye Kaptırmama Mücadelesinde”, Sputnik Türkiye, 18 Mayıs, https://tr.sputniknews.com/ceyda_karan_ eksen/202.005.181042078798-gelismeler-abd-cin-soguk-savasini-andiriyor-pekin-abyi-abdyekaptirmama-mucadelesinde/, accessed on 23.05.2020.

Kirchick, J. (2018). “Trump Wants to Destroy the World Order. So What?”, Foreign Policy, 26 July, https:// foreignpolicy.com/2018/07/26/trump-wants-to-destroy-the-world-order-so-what/, accessed on 13.06.2019.

Krastev, I. (2016). "Donald Trump and the Bieber Doctrine”, The New York Times, 20 November, https:// www.nytimes.com/2016/11/21/opinion/donald-trump-and-the-bieber-doctrine.html, accessed on 12.02.2019.

Küçükcan, T. (2017). “The Belt and Road Initiative and Middle Eastern Politics: Challenges Ahead”, Insight Turkey, 19(3): 83-91, DOI: 10.25253/99.2017193.06.

Kühnhardt, L. (2017). The Global Society and Its Enemies: Liberal Order Beyond the Third World War, Cham: Springer.

Mallaby, S. (2016). “Globalization Resets”, Finance \& Development, 53(4): 7-10.

Maull, H. W. (2019). “Global Disorder”, Uluslararası İlişkiler, 16(63): 3-12, DOI: 10.33458/uidergisi.621262.

Mazarr, M. J. (2017). “The Once and Future Order”, Foreign Affairs, 96(1): 25-32. 
Mead, W. R. (2017). “The Jacksonian Revolt: American Populism and The Liberal Order”, Foreign Affairs, 96(3): 2-7.

Mearsheimer, J. J. (2019). "Bound to Fail: The Rise and Fall of The Liberal International Order", International Security, 43(4): 7-50, doi.org/10.1162/ISEC_a_00342.

Niblett, R. (2016). “World Order in Peril”, Berlin Policy Journal, 31 August, http://berlinpolicyjournal.com/ world-order-in-peril/, accessed on 12.08.2019.

Niblett, R. (2017). “Liberalism in Retreat", Foreign Affairs, 96(1): 17-24.

Nye Jr., J. S. (2017). “Will the Liberal Order Survive?”, Foreign Affairs, 96(1): 10-16.

Özel, S. (2017). "Siyasetçiler ve Sınıf Savaşları", Habertürk, 03 Aralık, http://www.haberturk.com/yazarlar/ soli-ozel/1739052-siyasetciler-ve-sinif-savaslari\#, accessed on 25.09.2019.

Parmar, I. (2018). “The US-Led Liberal Order: Imperialism by Another Name?”, International Affairs, 94(1): 151-172, doi: 10.1093/ia/iix240.

Patrick, S. M. (2017). “Trump and World Order: The Return of Self-Help”, Foreign Affairs, 96(2): 52-57.

Patrick, S. M. (2020). "Under Trump, the US Has Become an Irresponsible Stakeholder", World Politics Review, 01 June, https:/www.worldpoliticsreview.com/articles/28802/under-trump-the-u-s-hasbecome-an-irresponsible-stakeholder, accessed on 20.06.2020.

Peterson, J. (2018). "Present at the Destruction? The Liberal Order in the Trump Era," The International Spectator, 53(1): 28-44, https://doi.org/10.1080/03932.729.2018.1421295.

Polanyi, K. (2002). Büyük Dönüşüm: Çağımızın Siyasal ve Ekonomik Kökenleri (A. Buğra Çev.), İstanbul: İletişim Yayınları.

Posen, B. (2018). “The Rise of Illiberal Hegemony: Trump’s Surprising Grand Strategy”, Foreign Affairs, 97(2): 20-27.

Reich, R. (2019). “Trump Has Turned His Back on The Working Class”, Newsweek, 26 December, https:// www.newsweek.com/trump-has-turned-his-back-working-class-opinion-1478952, accessed on 01.02.2020.

Rodrik, D. (2011). The Globalization Paradox: Democracy and The Future of The World Economy. New York: W. W. Norton \& Co.

Ruggie, J. G. (1982). "International Regimes, Transactions, and Change: Embedded Liberalism in the PostWar Economic Order”, International Organization, 36(2): 379-415.

Sachs, J. (2017). “The GOP’s Rush to Tax Cuts was Brainless”, CNN, 03 December, http://edition.cnn. com/2017/12/02/opinions/gop-tax-plan-brainless-sachs-opinion/index.html, accessed on 12.07.2019.

The Economist, (2016). "Globalisation Backlash 2.0”, 27 July, https:/www.economist.com/blogs/ buttonwood/2016/07/economics-and-politics-0, accessed on 30.08.2019.

Time, (2017). “The Republican Tax Bill's Winners and Losers”, 18 November, http://time.com/5030731/therepublican-tax-bills-winners-and-losers/?xid=homepage, accessed on 12.06.2019.

Tooze, A. (2019). "Everything You Know about Global Order is Wrong”, Foreign Policy, 30 January, https:// foreignpolicy.com/2019/01/30/everything-you-know-about-global-order-is-wrong/, accessed on 12.05.2019.

Trump, D. J. (2017). Yeniden Büyük Amerika: Gücünü Kaybeden Amerika’yı Ayağa Kaldırmak, İstanbul: Pegasus Yayınları.

Ulagay, O. (2017). Dünya Trump’a Mı Kalacak? “Tek Adam” Çıkmazı, İstanbul: Doğan Kitap.

Ülger, İ. K., (2019). “AB’nin İç Sorunları Derinleşiyor”, Anadolu Ajansı, 28 Kasım, https://www.aa.com.tr/tr/ analiz/abnin-ic-sorunlari-derinlesiyor-/1658118, accessed on 13.01.2020. 
Walt, S. M. (2016). “The Collapse of The Liberal World Order”, Foreign Policy, 26 June, http://foreignpolicy. com/2016/06/26/the-collapse-of-the-liberal-world-order-european-union-brexit-donald-trump/, accessed on 26.01.2019.

Walt, S. M. (2018). “The Donald versus “The Blob”', In R. Jervis, F. Gavin, J. Rovner, D. N. Labrosse (Eds.), Chaos in The Liberal Order: The Trump Presidency and International Politics in The Twenty-First Century, New York: Columbia University Press, 40-47.

Webber, D. (2014). "How Likely Is It That the European Union Will Disintegrate? A Critical Analysis of Competing Theoretical Perspectives", European Journal of International Relations, 20(2): 341-365.

Webber, D. (2018). European Disintegration: The Politics of Crisis in the European Union, London: Red Globe Press.

Yılmaz, B. (2017). "Küreselleşme ve 21. Yüzyılda Çözüm Bekleyen Sorunlarımız", Anadolu Ajansı, 21 Kasım, http://aa.com.tr/tr/analiz-haber/kuresellesme-ve-21-yuzyilda-cozum-bekleyensorunlarimiz/972674, accessed on 17.08.2019. 


\section{The Debate Over the End of the US-Led Liberal International Order:}

The Crisis of Liberalism and Its Future

\section{Ömer KURTBAĞ $\breve{G}^{*}$}

There has been an intensified debate in the Western World over the end of the liberal international order in the wake of the election of Donald Trump as US president in 2016. On this basis, the main argument of this study is that the post- 1945 liberal international order is now under serious threat, not only by the challenging rise of authoritarian global powers such as China and Russia, but also due to the wave of illiberal popular movements within the Western World. Thus, by analyzing a systemic (global) phenomenon such as the crisis of the liberal international order at both a state-based and a non-state based level, it aims to present a critical reading of the main works of liberals such as John Ikenberry $(2009,2010)$ whose analysis remains state-based. By doing so, the contention is that liberalism has failed to predict this illiberal popular movementsoriented outcome, and falsely believes that the existing order is only the victim of its own success and will eventually survive the current disarray, since it is essentially a crisis of US hegemony rather than that of liberalism itself, as will be outlined below.

The US led the formation of a liberal world order during, and in the aftermath of, the Second World War, and this outcome was not free from the establishment of the US hegemony at that time. Indeed the US sought to influence the shape and course of this order by leading the efforts to set up a network of international institutions including the UN, alliances such as NATO, the Bretton Woods twins, the IMF and the World Bank, and many others (Niblett, 2017; Patrick, 2017). This order was based on liberal principles and values, while the Soviet Union and its allies remained outside it. Other nations found it logical and reasonable to take part in this liberal order, while there was also a hierarchy between the US and its allies/partners. This US-led order managed to maintain the peace between the two blocs during the Cold War.

With the end of the Cold War however, some liberals argued that Western liberalism had been triumphant, and this signified the end of history. Indeed, the liberal international order had expanded and had become a genuinely universal order. On the other hand, the success of this

Erciyes University, FEAS, Department of International Relations, E-mail: omer.kurtbag@erciyes.edu.tr 
order was fraught with significant challenges and troubles. Among these were the unipolarity by which the US had lost its status as the provider of global commons, the quest for a new kind of Western interventionism justified on humanitarian grounds, but pursued inconsistently, and the increasing dysfunctionality of the Cold War era's nuclear deterrence regime. Then came the 9/11 terror attacks in 2001, which caused other nations to think that the US under Bush was no longer bound by the norms and rules of the liberal international order and might act unilaterally when it deemed it necessary to defend its national interests (Jahn, 2018). Therefore, just before the current debate with regard to the end of the liberal international order, there was a mounting crisis in terms of the legitimacy of this order.

In the second half of the 2010s, this order has been challenged by the revolt of the Western middle-classes, who felt forgotten by their own ruling elites, because of the economic hardships they are facing, the demographic and cultural dynamics which do not function in their favor, and the deterioration in their lives due to the wave of irregular immigrants, and lastly, due to the perceived loss of national sovereignty resulted from their countries' membership in international and supranational institutions (Mazarr, 2017). Against this background, the arrival of the Trump administration in 2016, alongside the Brexit referendum, was a breaking point in the debate over the future of the liberal international order, since Trump himself was markedly hostile to this order. His opposition to the free-trade agreements the US had concluded in the past, as well as the Obama-era deals such as the Paris climate accord, the Iranian nuclear deal, and the Trans-Pacific Partnership, was noteworthy in this regard. However, it is reasonable to argue that the US actions against the tenets of liberal order can be traced back to his predecessors, as the foreign policies of both the Bush and the Obama administrations were in violation of the norms and principles of this order.

The survival of this order seems to depend on whether or not any order-instituting actor would take responsibility for maintaining it in the face of the US abdication from its leading role, and whether or not it is possible to reform the conduct and functioning of liberalism within the Western world, most notably in the US. As the new champion of a liberal free-trade regime and of globalization, China is considered a potential architect of any order-building endeavor, but it faces significant challenges when it comes to fulfilling this formidable task. The EU remains the only Western actor which still clings to liberal internationalism. However, it has been busy with the financial crisis, the problem of irregular immigrants, and lastly the exit of the UK from the Union, all of which will have dire consequences for Europe. Given the lack of any serious reform effort on the part of the Western political elites of the liberal order, despite the popular backlash against it, therefore, liberal internationalism seems to be eroding further and evolving into a polity with less liberal and less American qualities. 